\title{
Measuring the Invisible: An Overview of and Outlook for Tax Non-Compliance Estimates and Measurement Methods for Switzerland
}

\author{
Felix SCHMutz ${ }^{\mathrm{a}}$
}

JEL-Classification: E26, H26, O17

Keywords: Shadow Economy, Underground Economy, Tax Compliance, Tax Evasion

\section{SUMMARY}

This paper gives an overview of tax non-compliance estimates and evaluates the suitability of various tax non-compliance measurement methods for Switzerland. The existing estimates for Switzerland focus strongly on non-declared assets and are based on a limited number of measurement methods. Nevertheless, the estimates range widely, between CHF 106 to over 500 billion for non-declared assets and 12.6 to 35.1 percent for income, for the time period 1970 to today. These estimates could be taken as a starting point for further tax non-compliance research. They should however be verified and supplemented by estimates resulting from other methods as a solid measurement of tax non-compliance requires a comprehensive approach including several methods. Further, the focus should shift from non-declared assets towards non-declared income.

a University of Lucerne, Department of Economics, Frohburgstrasse 3, PO Box 4466, 6002 Lucerne, Switzerland and Lucerne School of Business, Institute of Financial Services Zug (IFZ), Grafenauweg 10, PO Box 4332,6304 Zug. Email: felix.schmutz@hslu.ch. This paper is part of a doctoral thesis of Felix Schmutz at the University of Lucerne. Many thanks to Prof. Christoph Schaltegger, Prof. Rafael Lalive and two anonymous referees for their valuable input and comments. 


\section{Introduction}

Since the aim of tax non-compliance is to hide income or assets from being identified and taxed, quantifying and analysing tax non-compliance is a challenging task. This is also affirmed by the limited availability of literature on the extent of this activity in Switzerland. Despite its difficulty and limited empirical evidence, it is important to gather information on the extent and structure of the shadow economy ${ }^{1}$ and tax non-compliance ${ }^{2}$ because these data are relevant for social and economic policy as Schaltegger and Schneider (2005) outline. For example, an increasing shadow economy reduces the tax and social security base and may reflect an increasing social dissatisfaction with the state.

Concrete tax non-compliance estimates for Switzerland are limited and based on a very limited number of measurement methods. Not only are concrete figures scarce, but also a systematic overview, an analysis of the used methods in the context of Switzerland and an outlook for future research is missing. This paper aims to fill this gap by systematically summarising the available tax noncompliance estimates by tax type and comparing them with related measures. Further, the paper provides an outlook in which direction future research could head: the methods and results of tax gap estimates made by several European tax authorities are outlined as benchmarks, relevant taxes are identified and an analysis is given as to which methods are applicable and possibly effective in the specific case of Switzerland.

We find that the existing tax non-compliance estimates for Switzerland are based on a small number of measurement methods. Non-declared assets are mostly estimated based on non-reclaimed withholding tax figures and nondeclared income estimates are entirely based on comparisons between aggregated incomes according to tax versus national accounts (NA) statistics. Nevertheless, the figures estimated since the 1970s vary considerably: for assets, estimates range between CHF 106 billion and over CHF 500 billion (in prices of $2010)^{3}$ (see Table 6) and for incomes, depending on the year, between 13 and 35

1 Some authors use the expressions irregular, informal, underground, hidden, black or grey economy interchangeably with the expression shadow economy. We will refer to this from now on as shadow economy.

2 We prefer the expression tax non-compliance instead of the terms tax evasion or tax fraud commonly seen in the literature, as not every violation of tax law is wilful and some tax might not have been properly paid by mistake or due to the complex tax system. We will refer to tax evasion and tax fraud from now on as tax non-compliance.

3 The conversion from original to actual figures is based on the consumer price index with reference year 2010 . 
percent (see Table 7). These estimates can be taken as a starting point for future tax non-compliance research, but should be challenged by estimates derived with other measurement methods and data as there is no single best practice to measure overall tax non-compliance comprehensively. Combining several measurement methods and data sources allows to capture as much tax non-compliance as possible and to verify the consistency of any estimate. A cross-check of the estimates is necessary as the resulting tax non-compliance estimates must be interpreted with great caution. They can only be seen as a rough approximation since all methods have their methodological or practical deficiencies. Combining random audit programs with a comprehensive NA discrepancy estimate could deliver promising results, if random audit methods carry through politically and the strict data requirements of the NA discrepancy methods are fulfilled. Both methods need to be performed by, or at least in close cooperation with, the tax authority due to the resources, knowledge and data required. In a first step, the focus should be on non-declared wages and self-employed income, as the former contributes largely to the tax revenue and the latter is, according to the literature, prone to non-compliance.

This paper is organised as follows: After the introduction, a short overview is given of what is theoretically known about tax non-compliance, followed by the methods to measure the shadow economy and existing shadow economy estimates for Switzerland. Subsequently, tax non-compliance measurement methods are evaluated and tax-gap estimates by different European tax authorities analysed. Then, the focus is on Switzerland. Existing tax non-compliance estimates for Switzerland are outlined and an outlook is given as to where future research could head: we identify potentially relevant taxes regarding tax non-compliance and analyse which measurement methods are applicable to and potentially effective for Switzerland. The last section summarises, concludes and derives policy measures.

\section{Literature Review on the Theory of Tax Non-Compliance}

Tax non-compliance has been analysed for over forty years with various approaches and involving several academic disciplines (economics, econophysics, psychology and sociology). We identify four strands in the literature: Initially, tax non-compliance was theoretically modelled. Then, the models were empirically tested to identify tax non-compliance determinants, and individual tax compliance behaviour was analysed with laboratory experiments. Later, with the simulation of agent-based models, the social dynamics between different groups involved in the tax game could be modelled (PickHardt and Prinz, 
2014). These different approaches have also been combined (see BLoomQuist, 2011, as an illustrative example combining the empirical, experimental and agentbased approach). A main goal of tax non-compliance analysis, independent of the applied research approach, is to identify possible determinants, because knowing them allows implementation of efficient measures against tax non-compliance. Figure 1 summarises the disciplines involved, the approaches used and possible determinants of tax non-compliance.

Figure 1: Academic Disciplines, Research Approaches and Possible Determinants of Tax Non-Compliance

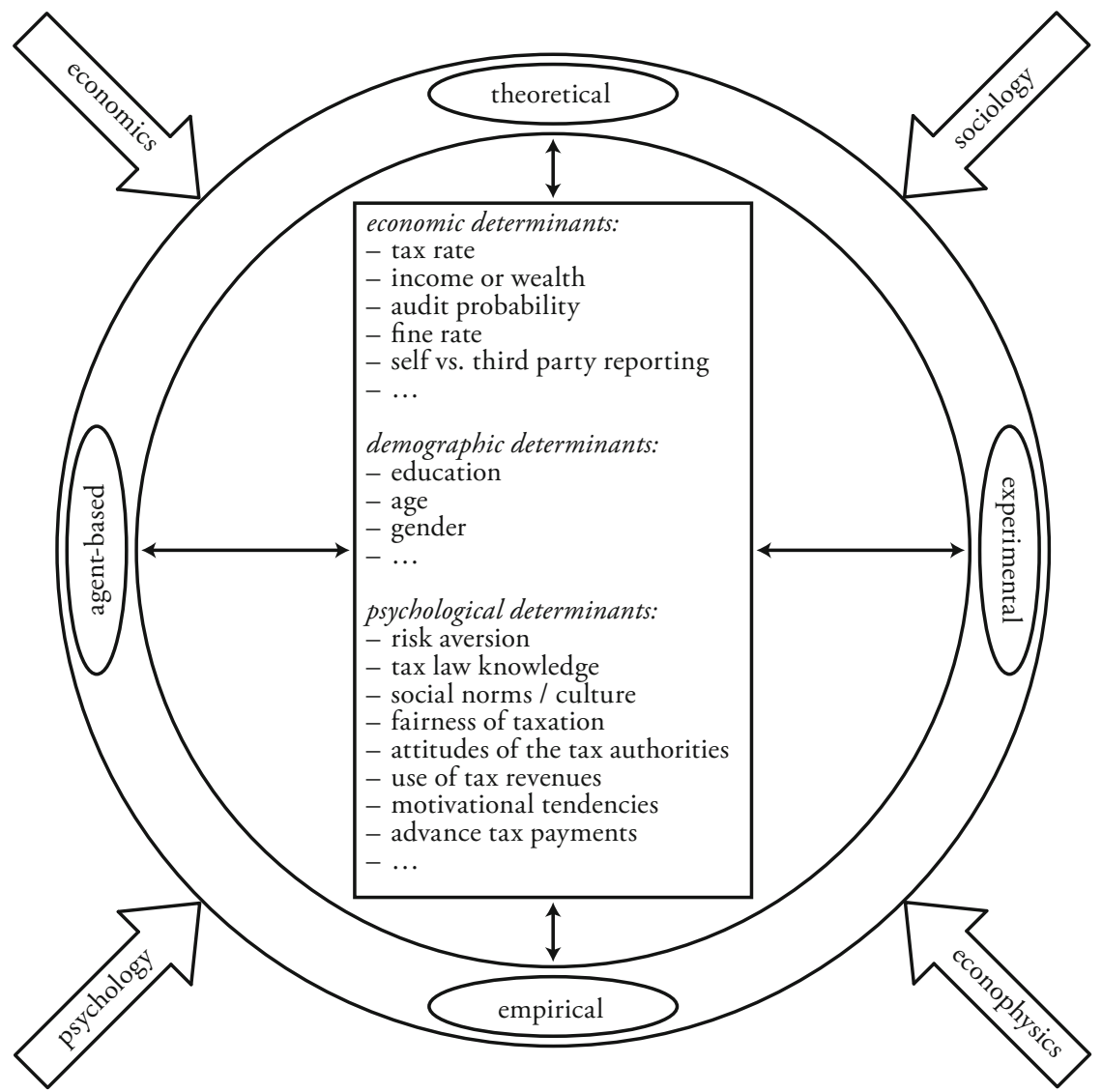

Source: Own illustration, partially based on Hofmann, Hoelzl, and Kirchler (2008) and PickHARD and PRINZ (2014, p. 5/Table 1). 
In the following, possible determinants and the most relevant developments in analysing tax non-compliance will be outlined briefly. The empirical approach will be neglected, as empirical capturing of tax non-compliance is already part of Section 4. For a comprehensive overview of tax compliance research over time and the involved disciplines see, for example, Pickhardt and Prinz (2014).

\subsection{Determinants}

A key aspect of analysing tax compliance is to identify relevant determinants as this allows implementing efficient policy measures against tax non-compliance. Initially, the focus was more on external economic variables such as tax rate, income, audit probability, severity of fines, unemployment rate and selfversus third party reporting. Over time, the focus moved to internal psychological variables such as risk aversion, tax law knowledge, personal and perceived social norms, perceived fairness attitudes toward taxation, the attitude of the tax authorities versus the taxpayers, motivational tendencies to comply, advance tax payments and use of the tax revenues. See Hofmann, Hoelzl, and Kirchler (2008) for a comprehensive review of the relevance of internal psychological and external economic variables regarding tax compliance. Especially social norm and factors influencing it such as religious beliefs (see PrInz, 2004), patriotism (see Konrad and Qari, 2009), social capital (see Alm and Gomez, 2008) or other cultural factors (see Alm and Torgler, 2006; Tsakumis, Curtola, and PorCANO, 2007) came into focus as tax compliance determinants. But also a possible relation between tax compliance and demographic factors such as education, age and gender has been analysed over the years (see, e.g., Chan, Troutman, and O'Bryan, 2000; Kasipillai, Aripin, and Amran, 2003, for education and Kastlunger et al., 2010; Torgler and Valev, 2010, for gender and age). For further details on tax compliance determinants see, for example, CEBula (2013) regarding income tax in the United States (US) or KirChLER et al. (2007) reviewing several tax compliance studies and concluding relevant factors for the compliance decision.

\subsection{Theoretical Approaches}

The standard model of tax non-compliance, developed by Allingham and SANDmo (1972) (A-S), combines economics of crime with portfolio and insurance theory under uncertainty. Each taxpayer has two possible strategies to maximize expected utility: to declare all or only part of the income. This strategic decision must be taken under uncertainty since the taxpayer does not know if he 
will be audited and penalized. The compliance decision depends on four factors in the A-S model: tax rate, income, audit probability and fine. A drawback of the A-S model is that it gives no definite answer as to whether tax non-compliance increases or decreases with an increase or decrease of income or tax rate. In an extension of the A-S model, YitzhaKi (1974) shows that under certain assumptions, a higher tax rate will always decrease tax non-compliance. This counterintuitive prediction was later known as the Yitzhaki puzzle. Many other extensions of the A-S model were developed over the years, often aiming to increase its plausibility - at the cost of complicating the model - as the baseline model omits potentially relevant factors. Alm (2012) states that many extensions were still relying on expected utility and economics of crime theory

... and include: expanding individual choices (e.g., labor supply occupational choice, sectoral choice, avoidance strategies); introducing alternative penalty, tax, and tax withholding functions; incorporating complexity and uncertainty about the relevant fiscal parameters; allowing the use of paid preparers; recognizing the provision of government services; giving individuals positive rewards for honesty; and allowing systematic audit selection rules in which the tax authority uses information from the tax returns to determine strategically whom to audit. (Alm, 2012, p. 62)

(See Andreoni, Erard, and Feinstein, 1998; Cowell, 1990; Sandmo, 2005; Slemrod, 2007; Slemrod and Yitzhaki, 2002; Torgler, 2007, for further explanations of the A-S extensions).

A main drawback of the original tax non-compliance models is that they seem to overestimate tax non-compliance (see, e.g., Mrles, Tran-Nam, and Hashimzade, 2010). To resolve this overestimation, caused by individuals tending to overvalue the audit probability and being risk averse, tax non-compliance models were developed which deviate from the expected utility theories (ALM, 2012). These models can include behavioral economics, assuming that individuals do not always act rationally, or the influence of social interaction on tax noncompliance (see, e.g., Myles, Tran-Nam, and Hashimzade, 2010).

Reasonable tax non-compliance levels can also be predicted with prospect theory (see, e.g., Dhami and AL-Nowaini, 2007, for further explanations of the prospect theory) as it allows for a convex loss value function, stigma, non-linear probability weights and loss aversion. Other advantages of prospect theory are that it allows to solve the Yitzhaki puzzle (Dhami and AL-Nowaini, 2007) and to support empirical and experimental evidence not supported under expected utility theory. For example, it has been used to show that advance tax payments influence tax compliance (Yaniv, 1999).

Another enhancement of classical tax non-compliance theory is to assume that social norm and interaction influences tax compliance, taking into account the 
evidence that taxpayers' non-compliance depends on the perceived tax compliance of their peers. TRAXLer (2010) improves the classical A-S model by including tax morale as a social norm for tax compliance. The more members of society practice tax non-compliance, the more it is accepted. There are other examples of studies accounting for social factors in their tax non-compliance models: Fortin, Lacroix, and Villeval (2007) include social interactions and Myles and Naylor (1996) a return for compliant taxpayers, Erard and Feinstein (1994) account for guilt and shame and Cowell and Gordon (1988) consider the expenditure side of the government budget.

\subsection{Experimental Approaches}

The first tax compliance experiment was conducted by Friedland, Maital, and Rutenberg (1978). Since then, experimental approaches have become popular in analysing tax non-compliance, because laboratory experiments allow to examine potentially relevant tax non-compliance factors that are not amenable in theoretical or empirical studies. Experiments allow, for example, testing of individual behaviour in reaction to exogenous changes (ALm, 2012) or the effect of social interaction on tax non-compliance (ForTin, Lacroix, and Villeval, 2007). Further, tax non-compliance models can be tested with experimental data (see, e.g., Fortin, Lacroix, and Villeval, 2007).

The main caveat of laboratory experiments is that inferring reliable conclusions outside of the laboratory is questionable, since individual decisions depend on social interaction, the decision context, financial implications and the selected participants (Levitt and List, 2007). See Alm (2012); Alm and Jacobson (2007); Pickhardt and Prinz (2014) for more information on experimental approaches.

\subsection{Agent-Based Models}

Agent-based models apply methods from computational and statistical physics as well as evolutionary and computational economics, but also consider psychological and sociological aspects, whereas their calibration can be done with experimental or empirical data. They are based on the assumption that different individuals or groups interact directly with each other and that their behaviour therefore depends on each other's behaviour. So the focus is often on the dynamics resulting from variation of the interaction or the enforcement process (Pickhardt and Prinz, 2014). For an illustration of how agent-based models can be used to analyse tax compliance aspects, see, for example, Hashimzade 
et al. (2015) or see BloomQuist (2006) for an example comparing three agentbased income tax non-compliance models. Further explanations of agent-based models and why they are especially apt to model the dynamics of tax non-compliance can be found in Pickhardt and Prinz (2014).

\subsection{Conclusion}

Initially, tax non-compliance theory was based on expected utility theory. However, based on expected utility theory, the predicted tax non-compliance was much higher than the expected non-compliance. Later, as an alternative, theoretical tax non-compliance models were based on prospect theory, yielding results more consistent with evidence, and the social norm as a determinant of tax compliance came into focus. A useful approach to consider social norm in form of social interaction as a determinant of tax compliance are computer agent-based models. Insights into tax compliance can also be gained from laboratory experiments, especially regarding individual tax compliance behaviour. Despite the wide range of methods and disciplines that have so far been used to analyse tax compliance behaviour, as illustrated in Figure 1, a main restriction in analysing tax compliance has not been overcome so far, as for example PickHardt and PrInz (2014) outline: reliable data is missing. This makes it impossible to test any theory on a solid ground. In our view, the best way to improve the base to test any theory is to increase empirical evidence.

\section{The Shadow Economy}

We include shadow economy measurement methods and estimates in this paper because some measurement methods are used to estimate both the extent of tax non-compliance and the extent of the shadow economy, and shadow economy estimates are used as approximations of, or as a basis for, tax non-compliance estimates. ${ }^{4}$ There is no universal opinion in the literature as to how close the relation is between the shadow economy and tax non-compliance. ${ }^{5}$

4 See, for example, Buehn and Schneider (2012) estimating time series tax non-compliance figures for 38 countries based on the MIMIC model shadow economy estimates of SCHNEIDER and Buenn (2012) for the time period 1999 to 2010. Depending on the considered factors, an average tax non-compliance for Switzerland of 0.8 or of 1.4 percent of GDP is calculated. See the study for details and results for the individual years.

5 See, for example, OECD (2002, pp. 140-146); SLEMrod (2007). 


\subsection{Shadow Economy Measurement Methods}

The prevalent methods of measuring the shadow economy are single or multiple macro indicator methods (see, e.g., Gemmell and Hasseldine, 2012; OECD, 2002, p. 192; SCHNeIder and Williams, 2013, for further explanations of these methods). They are based on the assumption that the invisible phenomenon to be measured cannot be completely hidden as it leaves observable traces. The most widely used single indicator method is the currency demand method. It assumes that transactions in the shadow economy are mainly based on cash payments and that cash demand is therefore related to shadow economic activities. Three main monetary methods exist: cash demand (see CAGAN, 1958; TAnzI, 1980), cash to deposit ratio (see Gutmann, 1977) and transaction method (see FeIGe, 1979) (see OECD, 2002, pp. 188-191, for a detailed explanation). ${ }^{6}$ Other common single indicators are electricity (see Kaufmann and Kaliberda, 1996) or labour participation rate (see Schneider and Buenn, 2013). The multiple indicators methods, called multiple indicators multiple causes (MIMIC) models, or the dynamic version, DYMIMIC, first introduced by WeCK (1983) and FreY and WeCk-Hannemann (1984) to measure the shadow economy, ${ }^{7}$ estimate the unobservable latent variable by replacing it with several observable indicators and by using several measurable causes of the latent variable. Combining the MIMIC with the currency demand method is a popular variant (see SCHNEIDER, 2015, for an example).

Advantages of macro indicator methods are their adaptability to many countries and the possibility of building time series. The required data is widely available and only limited resources are necessary. However, there are fundamental drawbacks. ${ }^{8}$ The single indicator methods have been criticised as early as 1983 by FREY and WECK (1983) for neglecting or restricting the determinants leading to the existence and increase of the shadow economy. Further, macro indicator methods are subject to controversial assumptions (see RuBIN, 2011). In the case of the currency demand method, it is assumed that all shadow economy

6 Another simplistic method related to currency is to analyse the development of the currency denomination in circulation. See Weck-Hannemann, Pommerehne, and Frey (1986, p. 28 f.) for details.

7 They used a LISREL (linear structural relationships) model, of which the MIMIC model is a special case.

8 See OECD (2002, p. 190 f.); Schneider and Enste (2000) for a critique on the currency demand and physical input method, Weck-Hannemann, Pommerehne, and Frey (1986, p.27); Schneider and Buehn (2013) for a critique on the labour force participation rate method and Breusch (2005) for a critical review of the MIMIC method and Dell'Anno and SCHNEIDER (2006) responding to this critique. 
transactions are in cash and that a base year exists either without or with known shadow economy (see SchneIder and Enste, 2000). The same disadvantage applies to the MIMIC method: only relative shadow economy estimates can be produced (FELD and SCHNEIDER, 2010). The MIMIC results are therefore only as reliable as the benchmark estimates. Also, the variables chosen in MIMIC models are questionable (OECD, 2002, p. 192). Given all these disadvantages, we agree with the OECD (2008) that macro indicator methods are not suitable for estimating a comprehensive GDP or underground production.

\subsection{Shadow Economy Estimates for Switzerland}

Table 1 gives an overview of shadow economy estimates for Switzerland with focus on the second half of the twentieth century to today, without claiming to be comprehensive. The figures, which are mainly based on macro indicator methods, show a trend by first increasing and then decreasing over time (see Figure 2). Further, in recent years, a concentration around 7 to 9 percent is evident.

Figure 2: Shadow Economy Estimates for Switzerland over Time (\% of GDP/GNP)

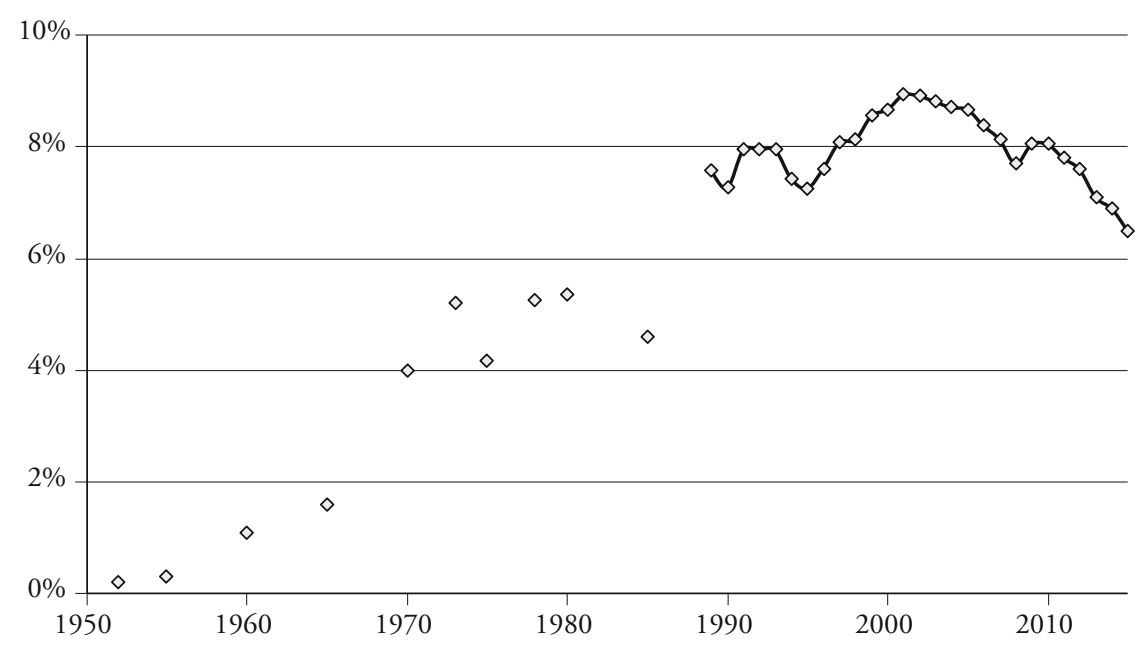

Notes: Data points correspond to yearly averages of the figures in Table 1; the figure from the experts' survey is not included; estimates over several years are included in each occurring year; if a range is given, the midpoint is taken.

Source: Based on figures from Table 1. 


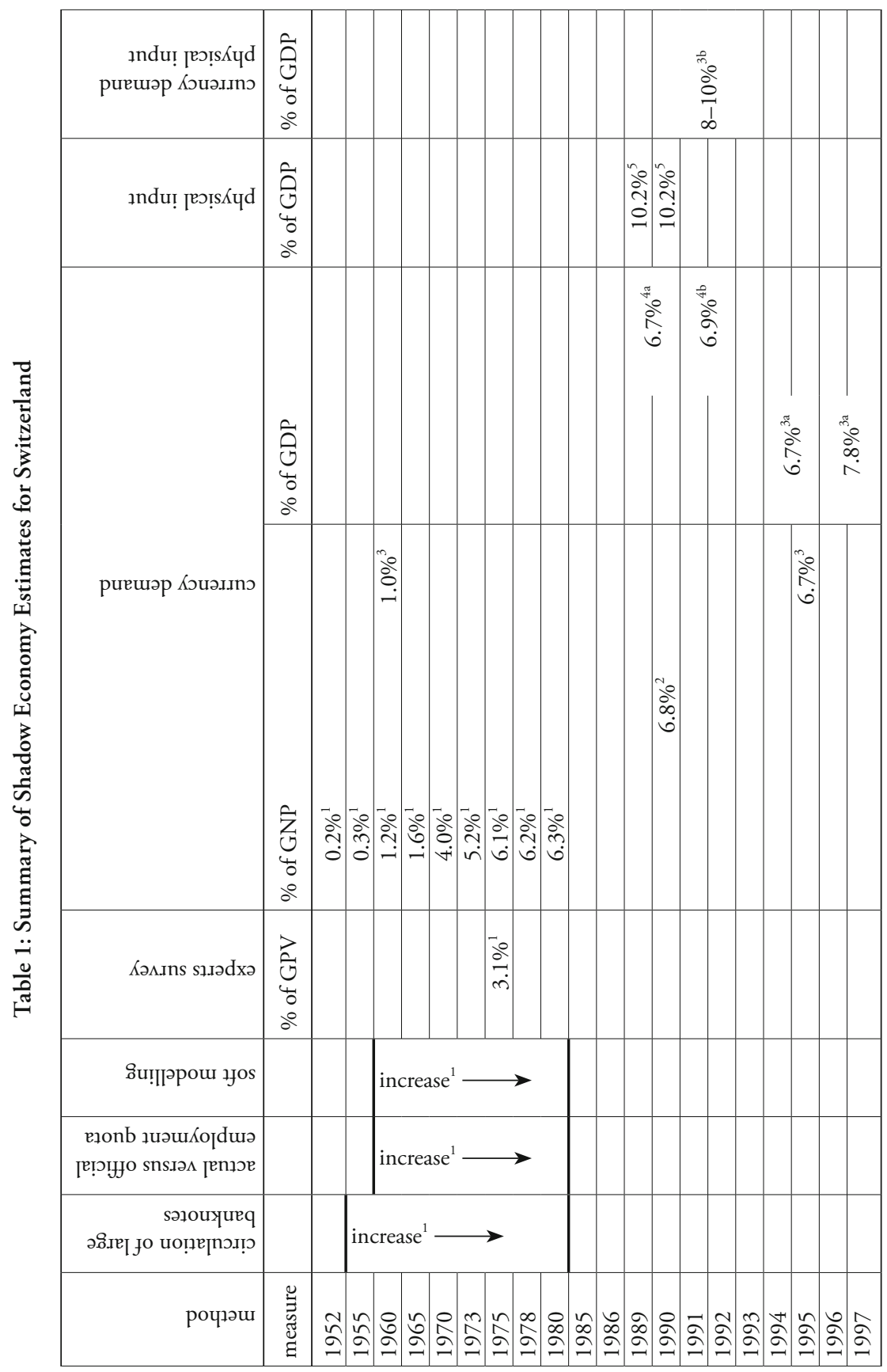

Swiss Journal of Economics and Statistics, 2016, Vol. 152 (2) 


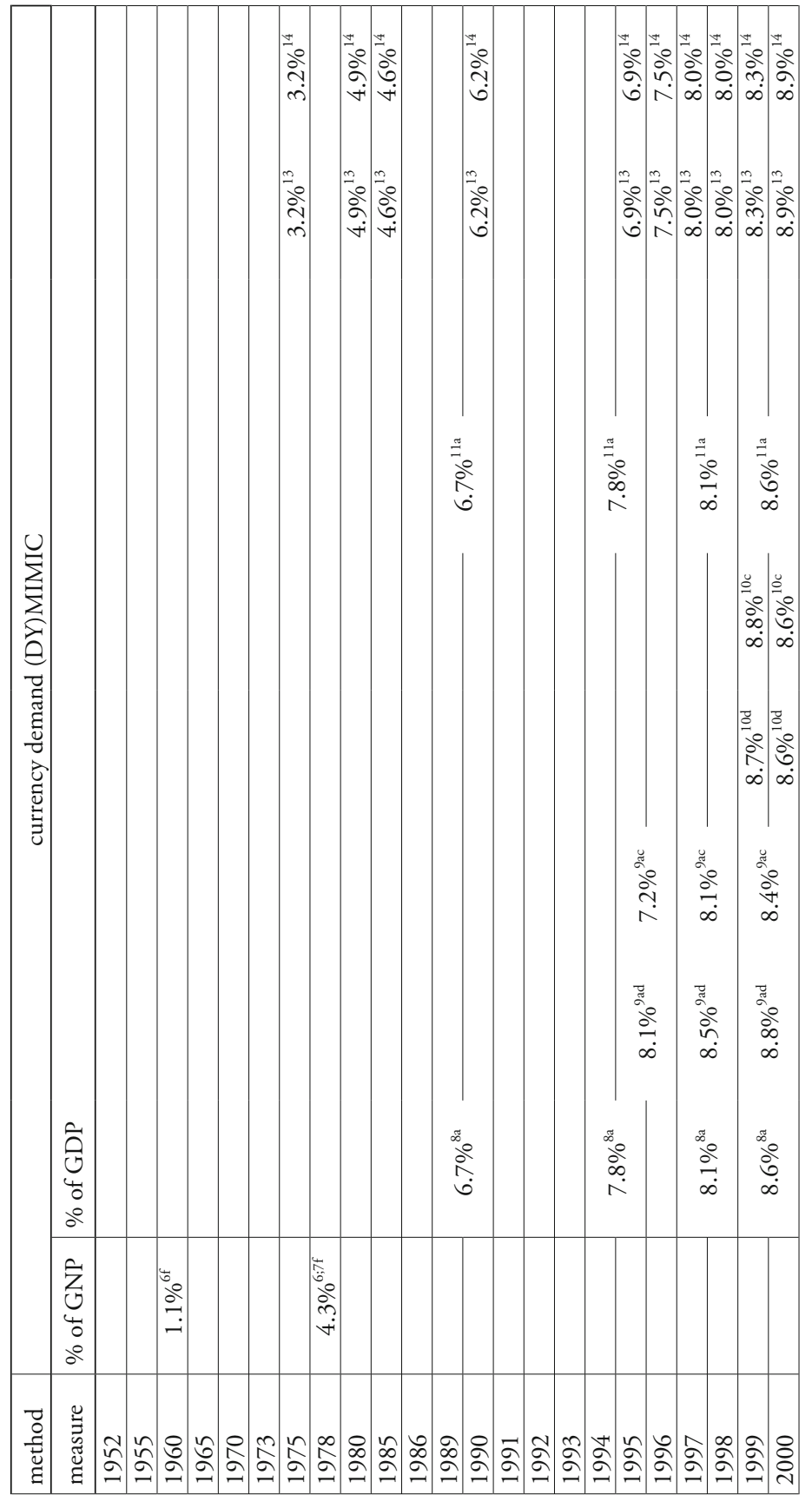




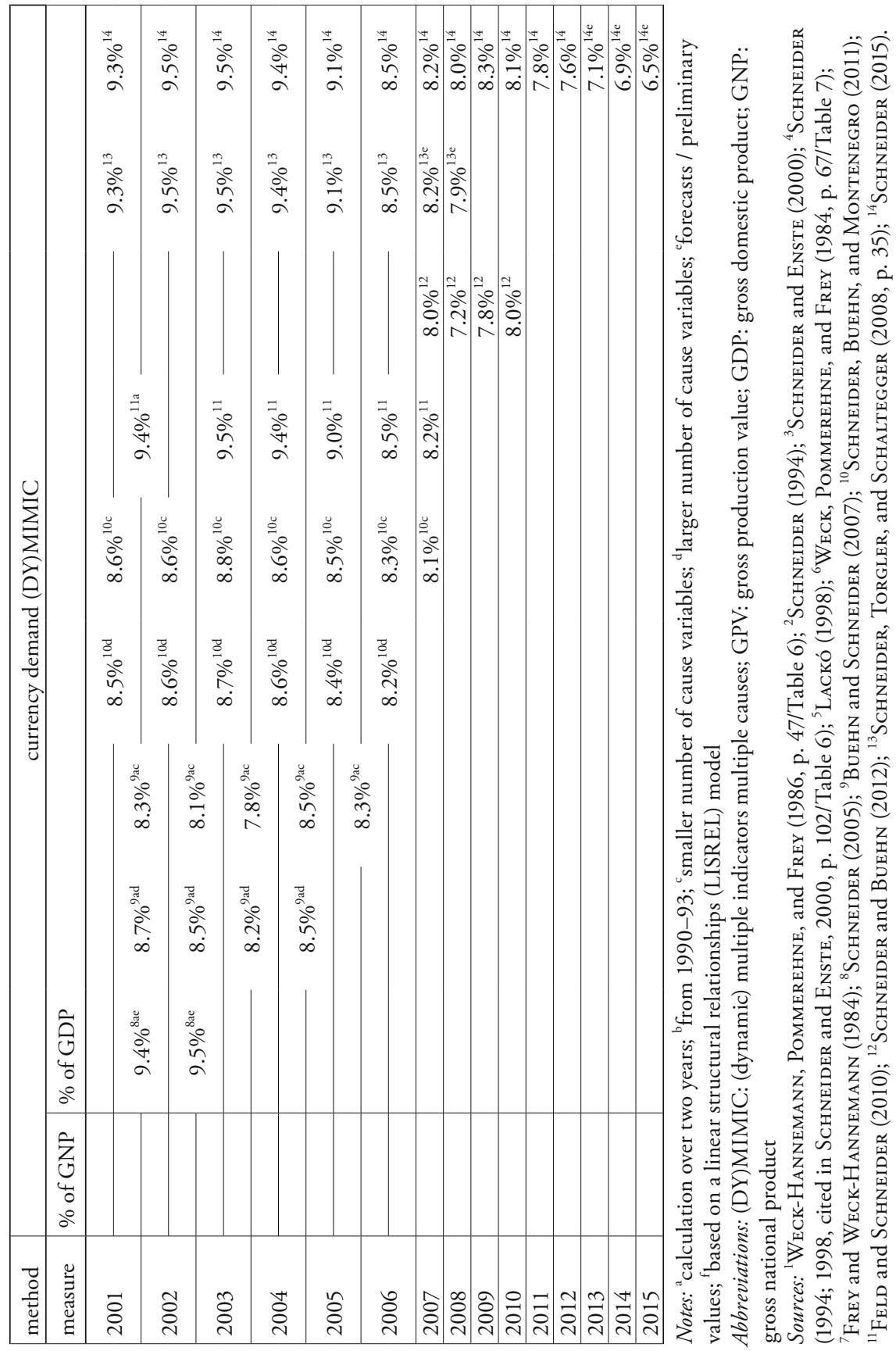




\section{Tax Non-Compliance Measurement Methods}

The common methods to measure tax non-compliance, listed with advantages and disadvantages in Table 2, can be divided into two broad categories: Macro or topdown methods are based on discrepancies between aggregated data, whereas micro or bottom-up methods use individual, business or household level data to identify tax non-compliance. ${ }^{9}$ Comparing these two categories, the former provides point estimates and allows estimates of time series, ${ }^{10}$ whereas the latter delivers valuable details about the structure of the tax gap, which can make them resource intensive. Point estimates are, as Rubin (2011) outlines, useful with moderate uncertainty, but as uncertainty increases, they can become meaningless, especially with small tax gaps. A persistent problem with many, but especially the macro measurement methods is estimating the appropriate tax rates for non-declared income or assets and accounting for interdependencies between the different tax types. ${ }^{11}$

\subsection{Macro Methods}

\subsubsection{National Accounts and Other Macro Discrepancy Methods}

Two different NA macro discrepancy methods can be distinguished measuring income tax non-compliance. The first one compares GDP measures calculated with the income versus expenditure (or production) approach. ${ }^{12 / 13}$ This method requires that the GDP income approach is based on tax statistics, the data used must be different to that used in the expenditure (or production) approach and its calculation needs to be fully independent of the other two GDP calculation approaches. According to the $\operatorname{OECD}$ (2002, p. 19), the last requirement is rarely met. The second NA method compares aggregated income according to NA versus tax data. This method requires that NA income figures are independent of tax data (as is the case in Switzerland, see Section 6.2.1).

9 The expressions macro and top-down, micro and bottom-up methods are not always used synonymously in the literature.

10 Changes over time may be caused by measurement errors and factors independent of changes in the hidden activity (see Gemmell and Hasseldine, 2012).

11 There is very little literature currently available which analyses this topic (GemmeLL and HasSELDINE, 2012).

12 The initial and not the published discrepancy between the NA estimates should be taken, since the aim of NA statisticians is to minimise this gap (SCHNEIDER and BueHn, 2013).

13 See OECD (2002, pp. 28-34) for further information on the three different GDP measurement approaches. 


\section{Table 2: Measurement Methods}

macro methods in general

+ - deliver point estimates and times series

- popular for indirect taxes

- deliver point estimates

- difficult to determine the appropriate tax rate and interdependencies between taxes

national accounts (NA) macro discrepancy methods

(NA versus tax data or NA income versus expenditure or production data)

$+\bullet$ based on a solid theoretical framework

- strict requirements on data quality and data availability

- difficult to reconcile the two data sets and to isolate the tax non-compliance effect

- activities outside of the NA not captured

\section{non-reclaimed withholding tax (WT)}

$+\cdot$ data availability

- simple methodic

- reliability of the method (dependence on capital market / difficult to split taxable and non-taxable persons / WT does not capture all asset income / 3 year time period to reclaim WT)

micro methods in general

+ - deliver details of non-compliance structure

- some methods are resource intensive

\section{taxpayer audits}

+ - seen as fairly reliable

- deliver details of tax non-compliance structure

- understatement of income / assets and overstatement of deductions identifiable

- the appropriate tax rate for non-declared income / assets is identifiable

- very resource intensive

- delivers lower bound as it captures only the auditable part of the tax non-compliance

- large burden on audited taxpayers

survey methods

$+\bullet$ useful in specific cases

$-\bullet$ reliability

micro discrepancy methods

+ - data availability

- based on a controversial assumption

- data reliability

- reconciliation of the two data sets

traces of non-compliance in consumption behaviour

+ - non-compliance derived in a subtle way

- applied in many countries (allows comparisons)

- not based on tax data

- data reliability

other micro methods

(laboratory and field experiments; tax amnesties; supplementary and penalty tax proceedings)

- • not suitable to capture absolute amount of tax non-compliance

Source: Own table. 
According to the literature, the NA macro discrepancy methods are based on a solid theoretical framework, but they have certain issues to deal with: comprehensive, complete and reliable data are required and the two sources compared must be made comparable by proper reconciliation, which requires solid and accessible documentation. Furthermore, the tax non-compliance effect must be isolated from discrepancies due to data problems and definitional or conceptual differences between the two data sets. Furthermore, taxable activities outside the scope of NA are not captured..$^{14}$ In our view, the reliability of the NA macro discrepancy methods depends crucially on how well the above mentioned requirements are met.

Other macro discrepancy methods also compare aggregate data from different sources to identify non-declared income or assets, but without taking advantage of NA data. Examples of these methods can be found in SKATteverket (2014) or HM Revenue \& Customs (HMRC) (2013b).

\subsubsection{Non-Reclaimed Withholding Tax}

Undeclared assets can be estimated based on the assumption that withholding tax is mainly non-reclaimed for income from assets which have not been properly taxed. This method is popular in Switzerland as the withholding tax gross revenue is publicly available and the method is based on a simple methodic. However, the Swiss Federal Council had already stated in 1983 that an estimate of nondeclared securities belonging to persons taxable in Switzerland based on withholding tax is not reliable. It is argued that the non-reclaimed amount in absolute terms depends on the capital market and that it is not possible to properly split it between taxable and non-taxable persons (see BundesRat, 1983). Other caveats of this method are that not all asset income is subject to withholding $\operatorname{tax}^{15}$ and that reclaiming withholding tax may occur in a later year than its collection. ${ }^{16}$ The withholding tax figures over the period 1994-2013 (see Figure 3) illustrate these issues. The non-reclaimed amount varies considerably over time, not only in absolute terms but also as a proportion of the total collected amount. This means that the amount of non-declared assets also varies accordingly across the

14 See Rubin (2011); Van de Laan and De Waard (1985, cited in OECD, 2002, p. 52) as examples reflecting these potential difficulties in applying the NA discrepancy methods in their results.

15 Income from Eurobonds, for example, is not subject to withholding tax (EIdgenössische Steuerverwaltung ESTV, 2013).

16 The recipient of the taxable earnings must request a refund of the withholding tax within three years after the calendar year in which the tax for taxable earnings was collected (EIDGENösSische Steuerverwaltung ESTV, 2014a). 
years if non-reclaimed withholding tax is an indicator. The percentage of total collected withholding tax reclaimed by foreign applicants also varies substantially over time, emphasising the difficulty of splitting the non-reclaimed part properly between taxable and non-taxable persons.

Figure 3: Withholding Tax Figures for Switzerland for the Time Period 1994 to 2013

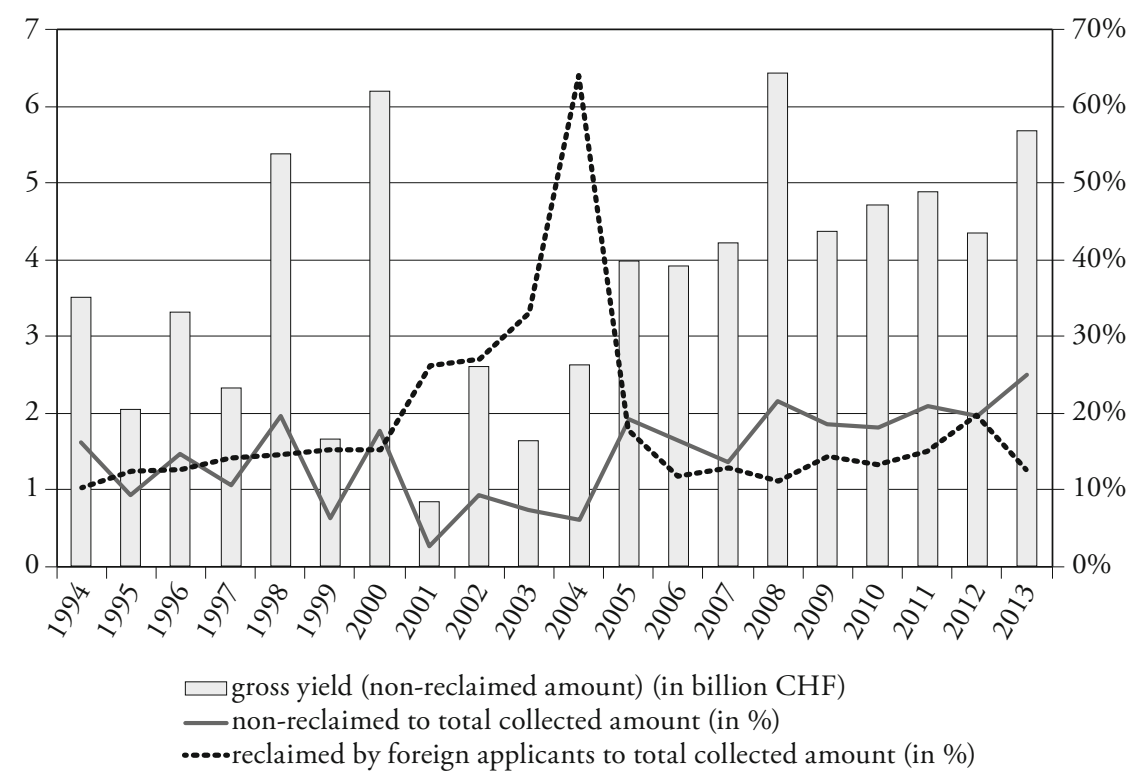

Source: Own illustration based on data from Eidgenössische Steuerverwaltung ESTV (2014b, p. 14).

\subsection{Micro Methods}

\subsubsection{Taxpayer Audits}

Tax audit methods involve careful auditing of a sample of taxpayers and extrapolating the results to estimate tax non-compliance for the entire population. Crucial to the explanatory power of the results is mandatory participation and avoiding sample bias. ${ }^{17}$ Taxpayer audit methods are generally seen as fairly reliable in

17 The results of the standard control work of the tax authorities are likely biased since the tax authorities usually target the most non-compliant taxpayers in their normal audit work (Ресно Trigueros, Pelaez Longinotti, and Sànchez Vecorena, 2012). 
the literature and are key to many tax gap estimates by tax authorities such as in Denmark (see SKAT - Danish Tax and Customs Administration (SKAT), 2013), the United Kingdom (UK) (see IMF, 2013) and the US (see Black et al., 2012; Brown and Johns, 2007). Further, various authors (see Fuest and Riedel, 2009; Gemmell and Hasseldine, 2012; Skatteverket, 2014) prefer tax audits to estimate tax gaps as they allow a detailed analysis of taxpayer noncompliance and therefore provide valuable information to the authorities. Moreover, overstatement of deductions can be identified and the appropriate tax rate for each non-compliant activity estimated. However, it must be noted that only the auditable part of the tax gap can be identified with taxpayer audits (SKATTEVERKET, 2014). A way to address this problem is by using multipliers (see ANDREoni, Erard, and Feinstein, 1998). Other main disadvantages of random audits are the resources required and the burden placed on the audited taxpayers, of whom at least some are innocent (see also OECD, 2004, for disadvantages of random audits).

\subsubsection{Survey Methods}

Information on tax non-compliance can also be collected through surveys. The largest caveat in the literature on survey methods is data reliability. Respondents may not remember their past reporting, they may not state the truth or not respond at all (see Elffers, Weigel, and Hessing, 1987, for an illustrative example of how unreliable surveys can be). The fact that tax evaders must admit their concealed income can be addressed by the survey design (Rubin, 2011). However, considerable uncertainty about the reliability of survey data remains even with sophisticated survey questions. Nevertheless, positive aspects of surveys used to analyse tax non-compliance can also be found in the literature. ScHNEIDer, Torgler, and Schaltegger (2008, p. 22) propose surveys to compare tax non-compliance and tax morale between societies. Even tax authorities rely on survey methods to measure specific aspects of their tax gap estimates (see HMRC, 2013b; Skatteverket, 2014; Swedish National Tax Agency, 2008) and the OECD (2002, p. 144) deems surveys useful to measure the invisible in specific cases, but not as appropriate for general tax non-compliance assessments. ${ }^{18}$

18 See Alm (2012); Pedersen (2003); Schneider and Buehn (2013) for advantages and disadvantages of survey methods. 


\subsubsection{Micro Discrepancy Methods}

The most common micro discrepancy method is to compare individual budget survey data with tax data, assuming the former includes true income figures, which is a rather controversial assumption. ${ }^{19}$ Preferably, the income figures can be directly linked individually between the two data sources. ${ }^{20}$ If individual matching is not possible, the comparison must be made at an aggregate level. ${ }^{21}$ Micro discrepancy methods are popular as the required data are available for many countries and even regions, but they are problematic because potential measurement errors and sample bias in survey data might exist and the two data sources being compared may measure different concepts. ${ }^{22}$

Micro discrepancy methods which compare tax data with data from sources other than surveys are often referred to as data-matching. ${ }^{23}$ For effective datamatching, the IMF (2013) requires comprehensive coverage with third party data which enables identification of all potential taxpayers as well as matching them between the two data sources, and which accounts for undetected undeclared liability. ${ }^{24}$

\subsubsection{Traces of Non-Compliance in Consumption Behaviour}

Some micro methods derive non-compliance based on consumption behaviour, assuming a close dependence between consumption and income. Fu (2008) identifies underreporting households by subtracting gross consumption from the income reported in a household survey, with consideration of saving behaviour. The critical requirement of this method is that individual independent income, expenditure and savings figures are available. The approach of Pissarides and WEBER (1989) uses a food consumption function to estimate underreporting

19 For a critical review of this assumption see, for example, Moore, Stinson, and Welniak (2000).

20 See Baldini, Bosi, and Lalla (2009); Paulus (2013).

21 See Benedek and Lelkes (2011); Fiorio and D’Amuri (2005); Matsaganis and FlevotoMOU (2010); Matsaganis et al. (2010).

22 Several studies (see Bollinger, 1998; Bound and Krueger, 1991; D'Alessio and Faiella, 2002; D’Aurizio et al., 2008; Kapteyn and Ypma, 2007) analyse discrepancies between different income data and ignore tax non-compliance as a possible source.

23 Another micro discrepancy method is the fixed point method: An auditor observes a taxpayer throughout a business day and then calculates the tax duty, based on the estimated turnover, and compares it with the taxes actually paid (see Pecho Trigueros, Pelaez Longinotti, and SÀnchez Vecorena, 2012, for further information).

24 See Alm, Bahl, and Murray (1991); HMrC (2013b); Kazemier (1990) for examples using data-matching methods. 
of self-employment income. ${ }^{25}$ This approach has been used in several countries since it was first published in 1989, sometimes with refined methodologies. ${ }^{26}$ This allows a comparison of the results across countries, although the details of the studies can differ. The main advantage of this approach is that potential noncompliance is derived in a subtle way, possibly not considered by non-compliers in their behaviour. The main disadvantages are that the estimate is not based on tax data and that the reliability of survey data is questionable. However, according to RUBin (2011), the British HMRC used this approach to cross-check the results of their 2005 random enquiry programme.

\subsubsection{Other Micro Methods}

Laboratory and controlled field experiments may be useful to examine taxpayer responses to a changing tax and social environment, ${ }^{27}$ but are unsuitable for capturing the absolute extent of tax non-compliance. For a critical review of laboratory experiments, see, for example, Alm (2012).

A potential indication of tax non-compliance can be derived from tax amnesties and supplementary and penalty tax proceedings figures. However, since not all non-compliant taxpayers participate in a tax amnesty or are obliged to pay supplementary or penalty taxes, these figures must been seen as absolute lower bounds and are therefore less informative.

\section{Tax Gap Estimates by Tax Authorities}

The methods used by tax authorities to measure tax non-compliance can be viewed as a benchmark since tax authorities have a great interest in solid estimates and tend to have more financial and personnel resources than others. In the following section, we present some tax gap estimates from European tax authorities. ${ }^{28}$ It is important to note that there is no unique definition of the tax gap and therefore, comparisons of measurement results must be made with caution, even

25 Feldman and Slemrod (2007) use a similar approach, but based on the charitable contributions reported on tax returns.

26 For example, Lyssiotou, Pashardes, and Stengos (2004) estimate the size of the shadow economy with a consumer demand system.

27 See Iyer, Reckers, and Sanders (2010); Kleven et al. (2011); Slemrod, Blumenthal, and Christian (2001) for interesting examples of controlled field experiments.

28 The worldwide most comprehensive tax compliance analysis was conducted in the US with the Taxpayer Compliance Measurement Program (TCMP) and the National Research Program (NRP) (Slemrod, 2007). 
when ostensibly, the same is measured: The British HMRC (2013a) includes tax avoidance in its tax gap definition, whereas others (see, e.g., Gemmell and HasSELDINE, 2012) do not. ${ }^{29}$ In the case of Denmark, unintentional errors made by taxpayers contribute to the tax gap (SKAT, 2009a).

\subsection{Denmark}

The tax gap in Denmark has been calculated since 1947 with a top-down approach using NA data. These macro estimates are seen as an important indicator for the health of the tax system, but not as sufficiently accurate and detailed (SKAT, 2009b). Therefore, the Danish Tax and Customs Administration (SKAT) nowadays compare bottom-up with top-down tax gap results (SKAT, 2009a). Random audit programmes were performed in the years 2006, 2008 and 2010, covering individuals as well as small and medium enterprises (SMEs). ${ }^{30}$ Not covered by the audit programmes are businesses with more than 250 employees. Also not captured by the audits are any non-declared activities or non-registered businesses (SKAT, 2013), but information on the hidden economy is provided by the Rockwool Foundation's interview investigations (SKaTteverkeT, 2014). The audits required 410 full-time equivalents (FTE) in 2006 and 150 FTE in the years 2008 and $2010^{31}$ and allow the SKAT to obtain a comprehensive picture of the tax gap differentiated by wage earners, self-employed and businesses. A tool is implemented to distinguish between deliberated tax non-compliance and errors (SKAT, 2013). For example, three-quarters of the total tax gap for private individuals in the year 2006 is viewed as purely the result of errors and only one-quarter, attributable to just 1 percent of all taxpayers, is seen as true tax non-compliance (SKAT, 2009a).

In the random audit tax gap investigations for the tax years 2006 and 2008, a high compliance level was found among individuals. The entire tax gap of private individuals (not including self-employed) calculated bottom-up amounts to 0.6 percent and 0.4 percent of the corresponding tax liability (SKAT, 2009a; 2013).

29 Although in theory, the difference between tax non-compliance and tax avoidance is clear, the former is illegal and the latter is legal, in practice, as for example Slemrod and Weber (2012) point out, the distinction between the two is often blurred.

30 The audit program for the tax year 2006 rigorously checked more than 22,000 individual taxpayers and companies selected by a stratified random sampling process (SKAT, 2009a).

31 In comparison, the HMRC dedicates a 1,270 staff to tackling the hidden economy (RAND Europe, 2008) and the Swedish Tax Agency allocates resources of 2,500 FTE to the tax gap (Skatteverket, 2007, cited in RAND Europe, 2008). 
An explanation for this high compliance rate might be that in Denmark, certain income information and deductions are automatically pre-entered into tax declarations of individual taxpayers. It is, however, worth noting that the personal income tax gap for the tax year 2006 calculated top-down with the NA method is about ten times higher than that calculated with audits results (SKAT, 2009a) (see SKAT, 2009a, for several possible explanations for this discrepancy). Table 3 summarises the bottom-up net tax gap figures for the tax year 2008 for Denmark.

Table 3: Summary of the Bottom-Up Net Tax Gap in Denmark for the Tax Year 2008

\begin{tabular}{|c|c|c|c|c|c|c|}
\hline & : & 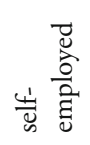 & 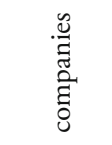 & 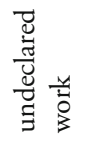 & 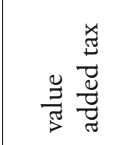 & 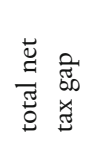 \\
\hline absolute ( $\left.10^{9} \mathrm{DKK}\right)$ & 1.1 & 4.8 & $3.1-3.6$ & 8.0 & $2.7-3.2$ & 21 \\
\hline$\%$ of tax liability (approx.) & $0.4 \%$ & $10 \%$ & $20 \%$ & $3 \%$ & $2.7-2.9 \%$ & $5 \%$ \\
\hline
\end{tabular}

no tax gap estimates are available for the following components

- large companies (> 250 employees)

- customs

- duties, motor, gaming, hydrocarbon etc.

Source: Based on SKAT (2013, p. 29).

\subsection{Sweden}

The Swedish Tax Agency (Skatteverket) analysed the tax gap in Sweden for the years 2007 to 2012 on behalf of the Swedish Government. The Swedish Tax Agency concludes that only a highly uncertain assessment of the change in the tax gap over the analysed years is possible, but not a quantification of the tax gap. For a bottom-up estimate, a greater number of random investigations would be required, and relying on top-down NA methods is not recommendable as the NA are classified as uncertain (Skatteverket, 2014). ${ }^{32}$ However, the Swedish National Tax Agency (2008) conducted a tax gap estimate during 2007 and calculated a total tax gap of 5 percent of the GDP corresponding to 10 percent of the determined tax. Undeclared work, estimated with a NA macro method, accounted hereby for approximately half of the tax gap. With various micro methods, able to explain about 91 percent of the amount of undeclared work estimated

32 In theory, the NA method is seen by the Swedish Tax Agency as the perfect measurement method to estimate the tax gap (Skatteverket, 2014). 
by the macro method, a breakdown into different taxpayer groups was done (and a remainder labeled 'undistributed' (p. 6)). The rest of the tax gap, besides undeclared work, was calculated using only micro methods. Whenever possible, different sources and calculations were compared. In cases without solid information for calculations, estimates are based on a 'reasonability assessment' (p. 6). Dividing the tax gap by tax type (see Table 4) reveals the largest absolute gaps in the areas of business income tax, social security contributions and value added tax (VAT). In percentage of the tax determined, tax on capital and business income tax have the highest percentages.

Table 4: Tax Gap by Tax Type by the Swedish Tax Authority in 2007

\begin{tabular}{|c|c|c|c|c|c|c|c|c|}
\hline & 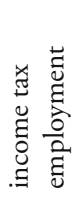 & 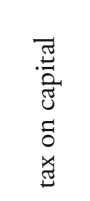 & 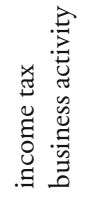 & 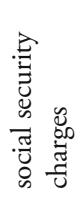 & 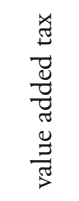 & 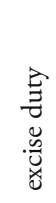 & $\frac{\vec{\Xi}}{\tilde{0}}$ & స్తి \\
\hline absolute ( $\left.10^{9} \mathrm{SEK}\right)$ & 20.4 & 10.9 & 31.9 & 30.2 & 35.3 & 4.2 & 0.6 & 133.5 \\
\hline$\%$ of tax reported & $5 \%$ & $65 \%^{1}$ & $33 \%$ & $8 \%$ & $14 \%$ & $5 \%$ & $4 \%$ & $10.7 \%$ \\
\hline
\end{tabular}

Notes: ${ }^{1}$ Tax gap related to total tax on capital income taken after deduction for deficit on capital (net calculation) / the tax gap amounts to 29 percent if related to the tax on total gross surplus of capital. Source: Based on Swedish National Tax Agency (2008, pp. 56/59-64).

\subsection{United Kingdom}

Her Majesty's Revenue and Customs (HMRC, 2013a) releases annual estimates of the net tax gaps for HMRC administered taxes. Depending on the tax type, either a top-down or bottom-up approach is used: tax gaps from indirect taxes such as VAT, excise duties and certain other indirect taxes are estimated with top-down methods and direct tax gaps are mainly based on bottom-up methods (HMRC, 2013a)..$^{33}$ Table 10 in the appendix gives an outline of the methodologies used to estimate the tax gap, showing the broadness of the methods. It also reveals that taxpayer audits, conducted within the employer compliance random enquiry programme, are key to the estimate. A weak point of this programme is that larger employers are not included. Therefore, findings from the random

33 The document "Methodological annex for measuring tax gaps 2013" by the HMRC (2013b) gives more explanations of the data and methods used to estimate the tax gap. 
program for SME employers are used as a proxy to estimate a tax gap for larger employers. This procedure was criticised by the IMF (2013).

The reported tax gap breakdown by behaviour in Figure 4 illustrates that not only classical tax evasion is taken into account, but also a wider concept of tax gap is analysed in the UK.

Figure 4: Breakdown of the United Kingdom Tax Gap 2011-12 by Behaviour

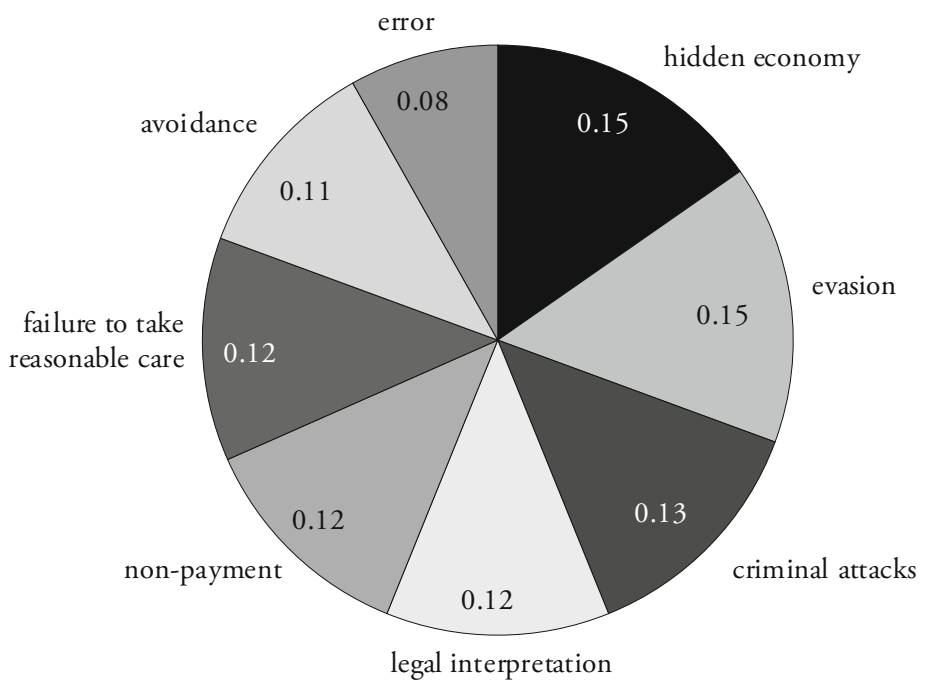

Notes: The percentage numbers do not sum to 100 percent due to rounding.

Source: Based on HMRC (2013a, p. 11/Figure 1.6).

The estimated tax gap 2011-12 is about 7 percent. ${ }^{34}$ Splitting the tax gap by tax type, as illustrated in Table 5, missing income tax (IT), national insurance contributions (NIC) and capital gains tax (CGT) contribute the largest part of the tax gap, accounting together for 44 percent, followed by the VAT gap with 33 percent and corporation tax gap with 13 percent. Putting the tax gap for each tax class in relation to the theoretical liabilities changes the picture. Then only 5.8 percent of the theoretical IT, NIC and CGT is missing, compared to 10.4 percent for VAT and 9.6 percent for corporation tax (HMRC, 2013a).

34 As audits can take several years to settle, figures are revised until all enquiries are made (HMRC, 2013a). 
Table 5: Tax Gap by Tax Type 2011-12 in the United Kingdom

\begin{tabular}{|c|c|c|c|c|c|c|}
\hline & 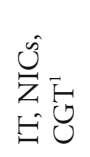 & 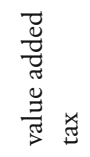 & 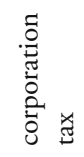 & 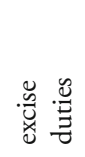 & 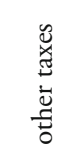 & ॠ్ర \\
\hline absolute $\left(10^{9} \mathrm{GBP}\right)$ & 15.3 & 11.4 & 4.7 & 2.5 & 1.1 & 35 \\
\hline $\begin{array}{l}\% \text { of total theoretical } \\
\text { liabilities }\end{array}$ & $5.8 \%$ & $10.4 \%$ & $9.6 \%$ & $4.9 \%$ & $4.2 \%$ & $7 \%$ \\
\hline
\end{tabular}

Notes: ${ }^{1}$ Income tax (IT), national insurance contributions (NIC) and capital gains tax (CGT). Source: Based on HMRC (2013a, pp. 6/10).

\subsection{Conclusion on Tax Authorities Experience}

There is no uniform picture of which tax types or non-compliance factors are most important for the tax gaps estimated by tax authorities. This is also owed to the fact that the tax gap definition as well as the structure and the focus of the tax gap estimates deviate considerably across countries. Therefore, a comparison between tax gap estimates has its limits. Nevertheless, certain tendencies can be observed: undeclared work is surely a main concern, as is non-compliance of micro companies and the self-employed. Corporate taxes seem to be of major relevance if measuring the non-compliance in percentage of the theoretical liability. But it must be kept in mind that for example the HMRC also includes tax avoidance in their tax gap measurement. A common feature of all illustrated tax gap analyses is the use of multiple measurement methods, sometimes even per tax or taxpayer type. Although a strong focus on random audit programs can be identified, the results of these audits are verified and supplemented by other methods. ${ }^{35}$ However, the involved tax authorities and the IMF stress to interpret the tax gap results with caution (see HMRC, 2013a; IMF, 2013; Swedish National Tax Agency, 2008).

35 See also OECD (2004) for the use of random audits of small and mid-size business taxpayers by tax authorities in OECD countries. 


\section{Tax Non-Compliance in Switzerland: Estimates and Outlook}

\subsection{Tax Non-Compliance Estimates for Switzerland}

Concrete figures on tax non-compliance in Switzerland are scarce and mostly outdated. ${ }^{36}$ The existing literature on tax non-compliance in Switzerland is reviewed by tax type and in chronological order, followed by related literature. The noncompliance estimates are reported in original value, with the corresponding amount in actual/2010-value in parenthesis.

\subsubsection{Non-Declared Assets}

Estimates of non-declared assets are available dating back to the 19th century (see Table 6, summarising the existing estimates of non-declared assets in Switzerland). However, the methods used to derive these early figures are generally not mentioned. Estimates from the $20^{\text {th }}$ and $21^{\text {st }}$ century usually report the estimate method.

The finance expert Prof. Grossmann (1938, cited in Munz, 1944, p.3) estimated that about CHF 18 (117-136) billion in assets were not declared in the period 1929/1932. In 1944, the Federal Tax Authority estimated the balance of shares, bonds and savings accounts and compared the proportion of said estimated balance taxable under the Wehropfer ${ }^{37}$ with the official declarations in the Wehropfer statistics. The difference amounts to CHF 6.2 (31) billion or 23 percent of the estimated balance (Eidgenössische Steuerverwaltung ESTV, 1944). Munz (1944, p. 14) argued that the difference is closer to 30 than 23 percent, because the absolute difference should be set in relation only to securities and assets subject to the Wehropfer tax. Munz (1944, p. 24 f.) further calculated that in total at least CHF 10 to 15 (51-76) billion in assets were insufficiently taxed, arguing that, in addition to the amount estimated by the Federal Tax Authority, further defraud was a result of overestimated liabilities and undervaluation and evasion of other assets not related to the Wehropfer.

In 1962, the Swiss Federal Council stated in an answer to a motion to the Federal Assembly that a quantitative estimate of the total loss due to tax non-compliance was not possible. The best estimate of tax loss might be made in the area of non-reported securities, bank accounts, banknotes and gold. Total moveable

36 There is more literature available regarding tax morale and its determining factors (see, e.g., Feld and Frey, 2006; Kirchgässner, 2007; Torgler and Schaltegger, 2006).

37 The Wehropfer was an extraordinary property tax levied by Swiss officials to finance defence costs (Eidgenössische Steuerverwaltung ESTV, 2010). 


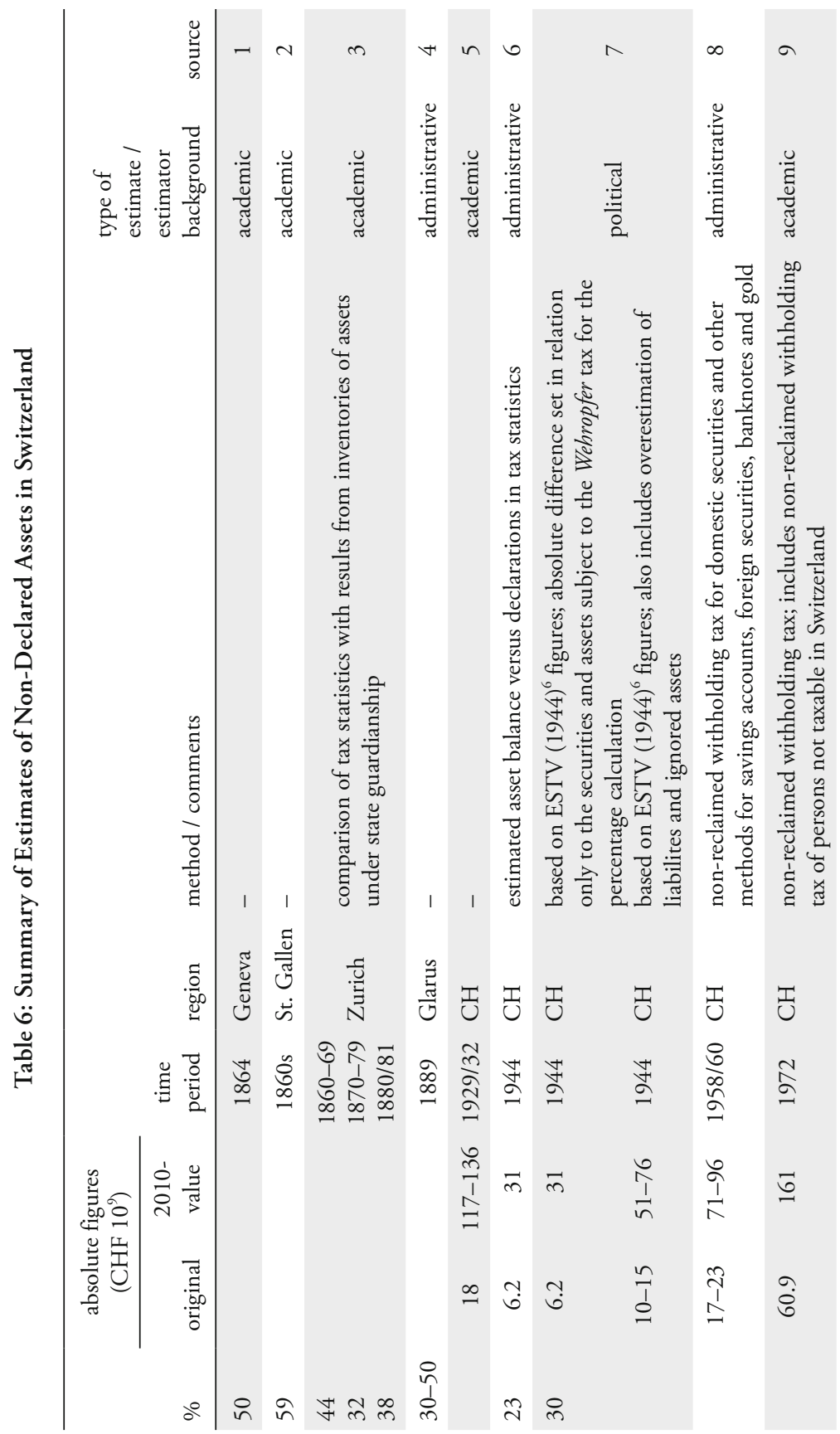




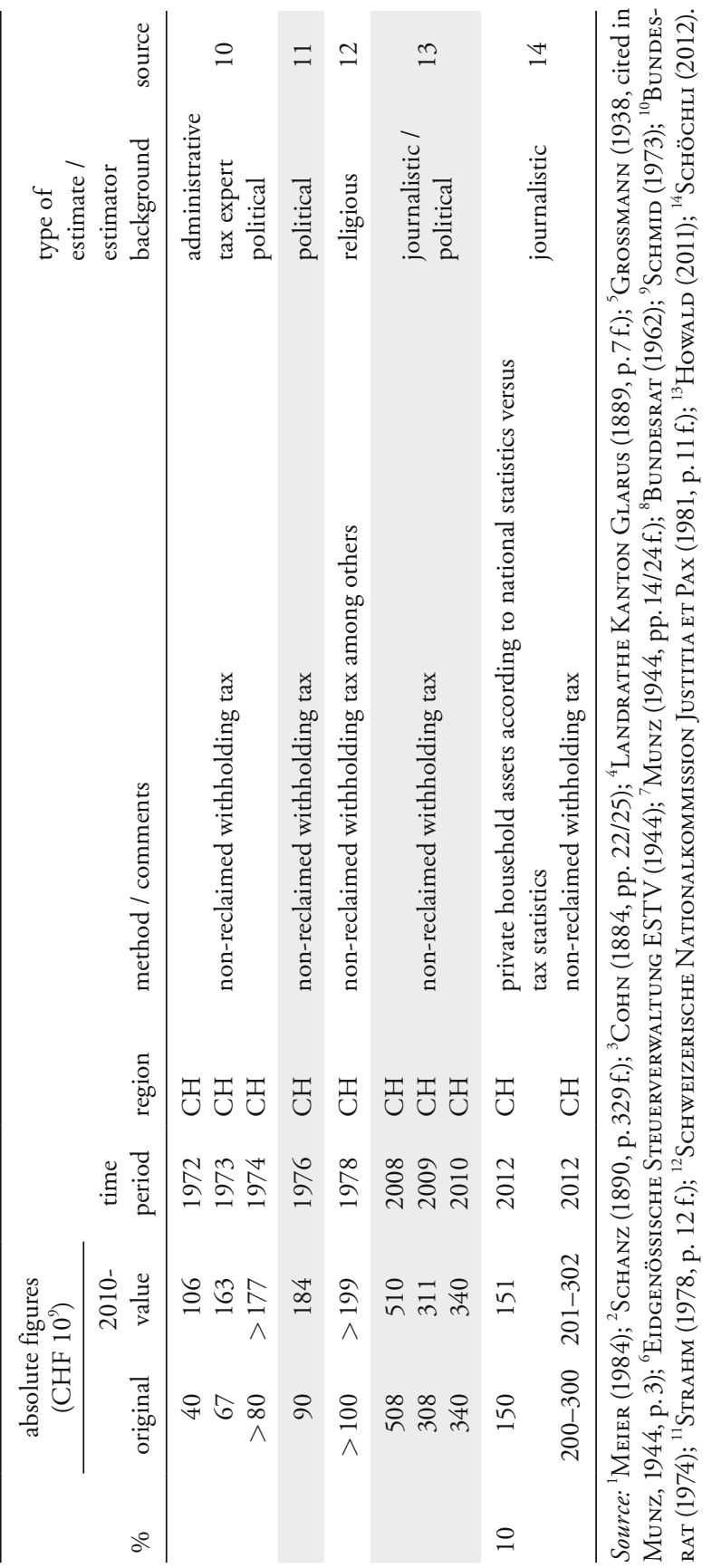


capital assets not reported to tax authorities was estimated at CHF 17-23 (71-96) billion and consisted of five components: domestic securities, savings accounts, foreign securities, banknotes and gold (BUndesRat, 1962).

A decade later in 1972, undeclared asset income of CHF 3.04 (8) billion and CHF 60.9 (161) billion in evaded assets was estimated based on non-reclaimed withholding tax. However, part of this belonged to persons not taxable in Switzerland (Schmid, 1973). At the same time, Council of States member Eggenberger asked the Federal Council in an official letter of enquiry if it deemed correct that an estimated CHF 67 (163) billion in securities was not properly taxed, as estimated by a tax expert and based on withholding tax revenue. Eggenberger also asked the Federal Council to produce, if possible, an official estimate of evaded assets. Council of States member Eggenberger calculated, based on the withholding tax revenue in 1974, that about CHF 4 (9) billion in interest earnings or over CHF 80 (177) billion in securities were not properly taxed. The Federal Council stated in its answer that an estimate of evaded assets could not be made based on gross earnings from withholding tax..$^{38}$ According to some approximate calculations made by the Swiss Federal Tax Authority, the relevant withholding tax gross revenue for the year 1972 amounted to about CHF $600(1,587)$ million and not to CHF $913(2,415)$ million as disclosed in the state account, resulting in evaded assets of about CHF 40 (106) billion by capitalisation with 5 percent (BundesRat, 1974). Another estimate based on non-reclaimed withholding tax stated that approximately CHF 90 (184) billion in assets, all subject to withholding tax, were not declared in 1976 (SтRAнм 1978, p. 12 f.). Based primarily on non-reclaimed withholding tax, ${ }^{39}$ Swiss National Commission Justitia et Pax estimated that assets amounting to over 100 (199) billion and generating an estimated yield of CHF 3.5 (7) billion were evaded in 1978, resulting in tax loss of about CHF $600(1,195)$ million. Other income elements were also not declared to the tax authorities, but it is impossible to estimate the amount even approximately (Schweizerische Nationalkommission Justitia et Pax, 1981, p. 11 f.).

Howald (2011) quantifies part of the total tax non-compliance based on nonreclaimed withholding tax potentially belonging to persons taxable in Switzerland. For the years 2008, 2009 and 2010 undeclared capital income of CHF 15.2 (15.3)

38 See Section 4.1.2 for the reasons why inferring from non-reclaimed withholding tax to defrauded assets is problematic.

39 For details on the estimation methods for non-declared assets in domestic bank and deposit books not subject to withholding tax as well as non-declared foreign securities in Swiss hands, see the original document (Schweizerische Nationalkommission Justitia et Pax, 1981, p. 42). 
billion, CHF 9.2 (9.3) billion and 10.2 (10.2) billion are estimated, corresponding to assets of CHF 508 (510) billion, CHF 308 (311) billion and 340 (340) billion if capitalised with 3 percent and resulting in a tax loss total of CHF 2.2 (2.2) billion in 2008, CHF 1.3 (1.3) billion in 2009 and CHF 1.5 (1.5) billion in 2010 if applying conservative tax rates. ScHöchli (2012) calculates an approximate estimate of the possible extent of non-declared assets in an article in the newspaper Neue Zürcher Zeitung by comparing the assets of private households according to national versus tax statistics. The difference amounted to approximately CHF 150 (151) billion (10 percent of total assets) after considering several conceptual differences, and was vulnerable to adjustments which would reduce or increase the estimate. ScHöchli (2012) concludes that the estimated CHF 150 (151) billion might be conservative, and based on withholding tax data, an amount of CHF 200 to 300 (201-302) billion might be assumed instead.

\subsubsection{Non-Declared Income}

In 1962, the Swiss Federal Council stated in an answer (already cited in Section 6.1.1) to a motion to the Federal Assembly that it was not possible to quantify the entire extent of income tax non-compliance, but nevertheless gave a general indication: the difference between total theoretical income according to NA and the income actually taxed was quantified at a minimum of CHF 2 (8) billion (BundesRat, 1962).

Weck-Hannemann and Pommerehne (1989) investigated undeclared income at cantonal level by comparing total household income reported to the tax authorities with income figures independent of tax data for the years 1965, 1970 and 1978. They looked at these years because cantonal income components were available which were as independent as possible of tax figures. According to the results - no specific tax non-compliance figures were stated - the independently captured primary income exceeded tax data income figures in every canton, indicating non-declared income. Pommerehne and Frey (1992, cited in FREY and FeLD, 2002) calculated a compliance rate of 82.5 percent for a sample of Swiss cantons. Some years later, Pommerehne and Weck-Hannemann (1996) repeated their comparison of gross household income in NA data with tax data for the years 1965, 1970 and 1978, again without naming any concrete tax noncompliance figures.

Building on the previous paper by Pommerehne and Frey (1992, cited in Frey and Feld, 2002) and Pommerehne and Weck-Hannemann (1996), Frey and FeLd (2002) widened the sample by adding the years 1985, 1990, 1995. The method of comparing national income gross household figures to adjusted 
household income reported to the tax authorities was maintained and a compliance rate of 76.52 percent was estimated. Referring to the figures of FREY and Feld (2002), Feld and Frey (2004) illustrate that, in the years analysed, the estimated level of income tax non-compliance, averaged over the Swiss cantons, ranged between 12.6 percent (1978) and 35.1 percent (1990) of gross household income and amounted to 22.3 percent in 1995 . Furthermore, in the two years 1970 and 1995, the estimates vary substantially between the cantons and the extent of tax non-compliance changed considerably over time. Table 7 gives an overview of the non-declared income estimates for Switzerland.

Table 7: Summary of Estimates of Non-Declared Income in Switzerland Based on Comparisons of National Accounts and Income Tax Data

\begin{tabular}{llllc}
\hline percentage & absolute & time period & region & source \\
\hline & min. CHF $2(8)^{\mathrm{a}} \times 10^{9}$ & $1958 / 60$ & Switzerland & 1 \\
$17.5 \%$ & $1965 / 70 / 78$ & sample of Swiss cantons & 2 \\
$23.5 \%$ & $1965 / 70 / 78 / 85 / 90 / 95$ & sample of Swiss cantons & 3 \\
$12.6 \%$ & 1978 & Swiss cantons & \\
$35.1 \%$ & 1990 & Swiss cantons & 4 \\
$22.3 \%$ & 1995 & Swiss cantons & \\
\hline
\end{tabular}

Notes: ${ }^{\mathrm{a}}$ In prices of 2010.

Source: ${ }^{1}$ Bundesrat (1962); ${ }^{2}$ Pommerehne and Frey (1992, cited in Frey and Feld, 2002); ${ }^{3}$ Frey and Feld (2002); ${ }^{4}$ FeLd and Frey (2004).

\subsubsection{Non-Declared Value Added Tax}

Newer estimates are available on VAT non-compliance. VAN BAALEN (2013) estimates the VAT gap bottom-up and top-down. The bottom-up figures are based on taxpayer audit results, which allows the main gap sources to be identified. For top-down figures, several VAT tax gap scenarios with different data sources are estimated for the period 2001 to 2008, varying between -3.1 and 8.6 percent of the actual revenue. The differences between the scenarios are greater than the fluctuations over time within each scenario.

Table 8 shows the bottom-up and the top-down benchmark scenario VAT gap figures. Generally, as expected, top-down figures are higher than bottomup, although the comparison is not straightforward since different time periods are used and the results strongly depend on the scenario. Further, van BAALEN (2013) points out that the results are sensitive and subject to a considerable error margin and that interpretation over time is difficult. 
Table 8: VAT Gap Estimates 2001-2012 in Percent of the Actual VAT Revenue

\begin{tabular}{|c|c|c|c|c|c|c|c|c|c|c|c|c|}
\hline & 㝏 & ণิ & ô & $\begin{array}{l}\stackrel{+}{o} \\
\stackrel{2}{\sim}\end{array}$ & 兑 & \& & 仓े & $\stackrel{\infty}{\stackrel{8}{8}}$ & & $\stackrel{\circ}{\stackrel{2}{\sim}}$ & $\overrightarrow{\vec{\sigma}}$ & $\underset{\sim}{\stackrel{\sim}{*}}$ \\
\hline bottom-up VAT gap & & & & & & & & 2.2 & 2.1 & 1.9 & 1.9 & 1.6 \\
\hline top-down VAT gap* & 6.9 & 7.9 & 7.6 & 6.5 & 4.7 & 3.5 & 5.2 & 5.1 & & & & \\
\hline
\end{tabular}

*benchmark scenario

Source: Based on van BaAlen (2013, p. 12 f./Tables 2/3).

\subsubsection{Related Literature}

The results of tax amnesties can be seen as an absolute minimum of tax non-compliance. Between 1940 and 2003, three national tax amnesties were introduced and many more at cantonal level (Torgler, 2003, p. 625). In the first of these amnesties in 1940, an additional CHF 1.5 (10) billion in assets was declared. In 1944, the next federal tax amnesty was in conjunction with the introduction of a withholding tax, and additional assets of CHF 6.5 (33) billion were declared (BundesRat, 1962). The third one took place in 1969 and assets amounting to CHF 11.5 (36) billion were uncovered (Schweizerische Nationalkommission Justitia et Pax, 1981, p. 11). Another tax amnesty is currently in place. Since 2010, under certain conditions and once per lifetime, taxable persons have been allowed to self-report tax non-compliance to the tax authorities without being prosecuted - according to federal law (Art. 175 Abs. 3 Bundesgesetz über die Vereinfachung der Nachbesteuerung in Erbfällen und die Einführung der straflosen Selbstanzeige).

Further studies exist which compare income figures from different sources (see Table 9 for the results). However, these state that tax non-compliance is only one of several possible sources for any measured difference or do not even consider tax non-compliance as a possible source. LARDI (1970, pp. 39-47) compares income according to tax and Federal Old Age and Survivors Insurance (Alters- und Hinterlassenenversicherung (AHV)) statistics with macroeconomic figures for 1961 and 1962. Wehrsteuer tax statistics capture 60 percent of personal income according to the NA whereas AHV statistics capture 78 percent. Combining tax and AHV statistics increases the percentage to 85 percent. LARDI (1970) states various reasons for this difference without mentioning tax non-compliance. Nотн (1975, pp. 85-89) compares aggregate net household income between tax statistics and NA and explains why the calculated income based on tax data should be lower than on NA. Two of the reasons he gives are tax avoidance and non-compliance. Therefore, the differences from 1940 to 1956 are seen as having the wrong sign 
or as being too low. Later, ERnst (1983, pp. 97-108) calculates net income using official statistics modified by a spot survey, and assesses the quality of his estimate by comparing it with aggregate NA household income. ERNST (1983) does not mention tax non-compliance as a possible cause for the differences.

Table 9: Difference in Percentage between Aggregate Income Based on Tax/Official Data and National Accounts Household Income for the Time Period 1940 to 1978

\begin{tabular}{|c|c|c|c|c|c|c|c|c|c|c|c|c|}
\hline 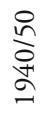 & $\begin{array}{l}\stackrel{N}{\approx} \\
\approx \\
\approx\end{array}$ & $\begin{array}{l}\stackrel{\Downarrow}{n} \\
\stackrel{n}{\approx} \\
\approx\end{array}$ & $\begin{array}{l}\stackrel{\wp}{n} \\
\approx \\
\approx\end{array}$ & 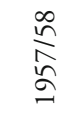 & $\begin{array}{l}\stackrel{\diamond}{\sigma} \\
\approx \\
\approx \\
\approx\end{array}$ & 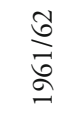 & 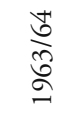 & 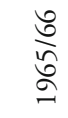 & 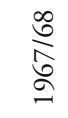 & $\frac{\stackrel{N}{N}}{\stackrel{N}{\Xi}}$ & $\stackrel{\infty}{\stackrel{\infty}{\beth}}$ & 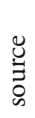 \\
\hline & & & & & & -15 & & & & & & 1 \\
\hline \multirow[t]{2}{*}{13} & 4 & -1 & -5 & -22 & -21 & -23 & -25 & -26 & -26 & & & 2 \\
\hline & & & -21 & & & & & -21 & & -19 & -15 & 3 \\
\hline
\end{tabular}

Source: ${ }^{1}$ Lardi (1970, pp. 39-47) (tax/AHV data); ${ }^{2}$ Noth (1975, p. 85/table 16) (tax data); ${ }^{3}$ Ernst (1983, p. 310/table A 2) (official data).

\subsection{Future Measurements of Tax Non-Compliance in Switzerland}

A comprehensive analysis of tax non-compliance covering all taxes would be desirable. However, considering limited resources, it is conducive to focus on relevant taxes. A tax type can be categorised as relevant in this context if it has a high contribution to the total tax revenue combined with a high susceptibility to non-compliance. Depending on the aim of the tax non-compliance analysis, the focus can also be placed on tax types with high relative non-compliance given as a percentage of the theoretical liability of the specific tax type.

The federal state structure is evident in the Swiss tax system. Taxes are imposed at federal, cantonal and municipal levels (Eidgenössische Steuerverwaltung ESTV, 2014a). The tax breakdown differs largely across the state levels (see Figure 5 in the appendix), emphasising that the identification of relevant taxes depends on the state level in focus. Since we are interested in the taxes on national level, we focus on the total tax revenue breakdown: about 39 percent of the fiscal revenue in the tax year 2011 is generated by income tax on natural persons, followed by VAT at 17 percent, corporate income tax at 14 percent, withholding tax at 5 percent, asset taxes on natural persons at 4 percent and other taxes sum up to a total of 21 percent (own calculation based on EIDgenössische Finanzverwaltung EFV, 2013, pp.36/46/57). 
An indication of the risk of non-compliance can be derived from the literature, taking into account that the legal and regulatory settings which influence the risk of non-compliance vary between countries as do the methodologies applied in the different studies. ${ }^{40}$

In the following, we analyse which taxes might be relevant for tax non-compliance and which tax non-compliance measurement methods could be appropriate in the case of Switzerland.

\subsubsection{Income Tax}

Income tax from natural persons finances the majority of the government budget in Switzerland. In addition, non-compliance in income tax from natural persons may often coexist with non-compliance in social contributions, thus increasing the adverse social impact.

In the literature, income from self-employment is seen as especially prone to non-compliance (see, e.g., Baldini, Bosi, and Lalla, 2009; BenedeK and Lelkes, 2011; Fiorio and D’Amuri, 2005; Matsaganis and Flevotomou, 2010; Pissarides and Weber, 1989). Furthermore, the experiences of Danish (see SKAT, 2013) and US tax authorities (see Christian, 1994; Slemrod, 2007) show considerably lower voluntary compliance among the self-employed compared to wage earners, and the Swedish tax authority identifies high non-compliance in micro companies (Swedish National Tax Agency, 2008).

It seems reasonable that the non-compliance potential for employment income with a payslip is limited and to a greater extent only possible in cooperation with the employer, especially when the annual pay statement is automatically sent to the tax authorities. ${ }^{41}$ The results of KLeven et al. (2011) are in line with this assumption. Their findings imply that while tax non-compliance for income subject to third party reporting is almost zero, it is substantial for self-reported incomes. However, it is likely that a certain amount of labour is not reported to the authorities, by mutual consent between employee and employer. PAulus (2013) reveals that about 20 percent of total employment income is not declared in Estonia and undeclared work contributes about 38 percent to the Danish net tax gap 2008 (SKAT, 2013) and about 50 percent to the Swedish tax gap (SwEDish National Tax Agency, 2008).

40 An issue in reviewing the existing literature is that many results are not published and/or no documentation of the estimate procedure is released (Schneider, Torgler, and SchaltegGER, 2008, p. 100).

41 This is, for example, the case in Canton Basel Stadt ( $\$ 157$ Abs. 1 lit. e Steuergesetz Basel Stadt) (tax law). 
Potentially effective to measure income tax non-compliance are the NA discrepancy methods. The first variant, however, comparing figures calculated using the income approach with those of the expenditure or production approach, cannot be implemented in the case of Switzerland as income data used in the NA is not based on tax data. Furthermore, according to the State Secretariat for Economic Affairs (StaAtssekretariat für Wirtschaft Seco, 2008), the GDP calculation based on income factors employs a residual measure: the net operating surplus, including self-employed income and corporate profits, results as the remaining balance. This means that any potential measurement errors in national income accounting are reflected in the resulting net operating surplus. It is further interesting to note that according to an earlier comparison of income and expenditures in the NA by WeCK-HaNnEMANN and Frey (1985, p. 84), income tended to be greater than expenditures, reflecting considerable measurement problems. Hence, it seemed plausible for Weck-Hannemann, Pommerenne, and FrEY (1986, p. 22) to assume that the discrepancy between expenditures and income in the NA is a biased indicator of the size of the shadow economy.

The second NA discrepancy method, which compares NA income data with income declared to the tax authorities, seems more appropriate in the case of Switzerland. However, it needs detailed clarification as to whether it is possible to separate tax non-compliance from other conceptual and measurement differences in the two databases. Especially as, according to the Swiss Federal Statistical Office, the income approach plays only a secondary role in NA calculation in Switzerland (OfFice fÉdéral de la statistiQue OFS, 2013), and previous reconciliations of aggregate net income figures with NA income data, which do not focus on tax non-compliance, such as those of Noth (1975) or ERNST (1983), show results similar to those explicitly focusing on non-compliance, such as PoMmerehne and Frey (1992, cited in Frey and Feld, 2002); Frey and Feld (2002) or Feld and Frey (2004).

Instead of using NA data, tax data can also be compared with other comprehensive income data sources. In Switzerland, AHV data should have comprehensive coverage of earned income. However, a comparison of tax and AHV data could deliver, at most, an absolute lower bound of non-compliance since most compensation subject to and declared to the AHV can be assumed to be taxed correctly. Comparing AHV with tax data from the self-employed will hardly give insight into tax non-compliance, since, as mentioned in AHV/IV (2014), the contribution of the self-employed to AHV is determined based on the tax assessment.

Within the micro methods, random taxpayer audits could been seen as relatively reliable to measure income tax non-compliance, although they only yield 
a lower bound (see Section 4.2.1). However, the legal basis must be given to perform random taxpayer audits and it could only be done by the tax authorities due to the knowledge and resources required, the mobilisation of which is a political question. Beside the high costs, random taxpayer audits may be questionable from a societal viewpoint because of the time burden placed on the audited taxpayers, of whom at least some are innocent.

We view discrepancy methods, comparing income according to household budget surveys, which are detailed and available in Switzerland, with income on tax forms, as useful if the two databases can be matched at the individual level. ${ }^{42}$ In this case, these methods could, despite the controversial assumption that the respondents reveal a more accurate income in household budget surveys than on tax forms, be used to support and complement other income tax noncompliance estimates.

The approaches of Pissarides and Weber (1989) and Fu (2008) are also based on household budget surveys. The former identifies income underreporting by self-employed compared to wage earners. This could be especially promising taking into account the potential non-compliance of the self-employed. Again, the explanatory power of this method could be considerably increased by individually comparing the income declared in the budget household survey with that on tax forms. ${ }^{43}$ The approach of Fu (2008) is not applicable in Switzerland because, to our knowledge, there is no data source available that captures income, expenditures and savings independently at the individual level. ${ }^{44}$

\subsubsection{Value Added Tax}

VAT gap estimates are, relative to other taxes, widely available, and newer topdown and bottom-up figures also exist for Switzerland. ${ }^{45}$ Especially popular are estimates of the VAT gap based on macro methods. Potential explanations for this can be found in Gemmell and Hasseldine (2012) and Rubin (2011). Gemmell and Hasseldine (2012) argue that it is usually easier to calculate the theoretical tax liability for indirect rather than for direct taxes because for indirect taxes,

42 This may not be possible for data privacy protection reasons.

43 This method is based on the assumption that the income declared in household budget surveys and on tax forms is identical.

44 The household budget survey contains detailed individual income and expenditure figures for Switzerland, but the published saving amount is calculated as the difference between reported income and expenditures (Bundesamt FÜR STATISTIK BFS, 2013).

45 For details of method and results for European Union countries, see ReCKON LLP (2009) and for Switzerland, see van BaAlen (2013). 
data collected independently from tax data is frequently available. Rubin (2011) points out that indirect tax liability depends less on individual circumstances.

The literature indicates that VAT non-compliance is not negligible, although tax non-compliance might not be the only cause for VAT gaps, as outlined in RecKon LLP (2009). The estimated VAT gap accounts for 33 percent of the tax gap in the UK for 2011-12 (HMRC, 2013a) and for about 14 percent of the total Danish net tax gap for the tax year 2008 (SKAT, 2013). A report with VAT gap estimates for 26 European Union countries for 2011 shows significant differences between the countries: from 2 percent of VAT total theoretical liability (VTTL) in Sweden to 48 percent of VTTL in Romania. The neighbouring countries of Switzerland have VAT gaps expressed in percentage of VTTL of 12 and 13 percent in Germany and Austria, 19 percent in France, and 27 percent in Italy (CPB Netherlands Bureau for Economic Policy Analysis, 2013). These figures are considerably higher than the VAT gap estimates for Switzerland (see Table 8).

\subsubsection{Corporate Tax}

Analysing and measuring corporate tax non-compliance is even more difficult than for other tax types as the distinction between tax non-compliance (illegal activity) and tax avoidance (legal activity) is often not straightforward. This leads to high uncertainty in estimating the corporate tax gap. The Swedish Tax Agency concludes that the greatest uncertainty in estimating the tax gap is with regard to international connections or large companies, since such companies often operate in grey areas (Swedish National Tax Agency, 2008). Reviewing existing studies, it is important to note that some, for example HMRC (2013a), also include tax avoidance in their tax gap estimate. It seems reasonable that the amount of evaded, as opposed to avoided, corporate taxes is rather low, especially in large and public companies, due to external control mechanisms and the fact that the detection risk increases with the number of people involved. The methods most suitable for measuring corporate tax non-compliance are, as for income tax, the NA discrepancy methods and taxpayer audits, despite all the caveats mentioned in Sections 4.1.1, 4.2.1 and 6.2.1.

\subsubsection{Asset Tax}

Non-declared assets are a concern for tax authorities for two reasons: they lose tax revenues both from taxation of the assets themselves and from the yield of these non-declared assets. With the introduction of withholding tax, the negative effects of not declaring asset income was heavily reduced, whereas the adverse effects of non-declared assets and the related reduction of tax revenues remain. 
However, the interest in measuring asset tax non-compliance might further decrease as the transparency regarding asset wealth increases in line with more intensive international cooperation and data exchange.

In Switzerland, the majority of all tax non-compliance estimates are related to non-declared assets (see Table 6). But these estimates should be verified with other methods, as the newer estimates are almost entirely based on non-reclaimed withholding tax. A comparison with asset non-compliance estimates from other countries or deriving the importance of non-declared assets for total tax noncompliance based on international literature is rather difficult as, according to Gemmell and Hasseldine (2012), literature on the tax gap of property taxes is generally scarce. Reasons for this might be that property taxes are not a major tax source in most OECD countries, if assets are taxed at all, and in any case, immovable property is rather difficult to hide. ${ }^{46}$ Further, asset income is not always straightforward to measure and to report for the taxpayers themselves. This increases the unintentional error rate and decreases the explanatory power of tax gap estimates. The Danish tax authorities (SKAT, 2009a) identify by far the highest error proportion in individual tax returns in the section other income from capital.

\section{Conclusion}

There is no single best method to measure overall tax non-compliance in Switzerland comprehensively. An appropriate method depends on various factors such as the required level of detail of the analysis, the available resources and data or tax type in focus. Further, as any method has its practical or methodological deficiencies, any tax non-compliance estimate must be interpreted with caution and seen as a rough approximation. Multiple methods and data sources should be used. This allows capturing as much tax non-compliance as possible, but also to cross-check and verify the consistency of any estimate. An example of this approach are the tax gap estimates of many tax authorities: ${ }^{47}$ even though

46 Property taxes accounted for only 5.4 percent of total taxation on OECD average in 2011, with a minimum of 1 percent in Estonia and a maximum of 12.4 percent in the US (OECD, 2013, pp. 27/115). In Switzerland, withholding tax accounts for 5 percent and asset taxes on natural persons for 4 percent of the fiscal revenue in the tax year 2011 (own calculation based on Eidgenössische Finanzverwaltung EFV, 2013, pp. 36/46/57).

47 For example in Denmark (see SKAT, 2009a; 2009b), the UK (see HMRC, 2013a; 2013b) or the US (see BLACK et al., 2012). 
a strong focus on random audit programs can be identified, these tax gap estimates are based on several measurement methods.

In Switzerland, the existing tax non-compliance figures could be taken as a starting point, but should be challenged and supplemented by further research and estimates. Especially because the available estimates focus strongly on nondeclared assets and the variety of methods and data used is limited. The newer estimates of non-declared assets are almost entirely based on non-reclaimed withholding tax and those estimating non-declared income are based on the NA macro discrepancy method. Nevertheless, estimates since the 1970 s vary widely between CHF 106 and CHF 510 billion in actual (2010) prices for non-declared assets and between 12.6 percent and 35.1 percent for non-declared income, depending on the year. A point estimate cannot be expected in the future, but the wide range of the estimated figures should be narrowed. The focus should shift from estimating non-declared assets to estimating non-declared income. Preferably, non-compliance in the declaration of wages and pensions and on self-employed income should be analysed, because wage earnings and pensions contribute significantly to the tax revenue and in the literature, selfemployed income is seen as prone to non-compliance. Verifying top-down estimates of income non-compliance, if applicable based on the NA macro discrepancy method, with bottom-up estimates, preferably from taxpayer audits, seems promising. These estimates could be supported by the micro discrepancy and Pissarides and WeBer (1989) methods, especially if an individual comparison of the income according to household budget survey and tax data is possible at household level. The VAT gap also seems relevant for the whole tax gap, but newer estimates already exist.

In our opinion, if it is possible at all, a comprehensive measurement of total tax non-compliance can only be done by the tax authorities due to the resources needed and data and information required. Single aspects or components of tax non-compliance can also be analysed by others. Whether the cost-benefit ratio of analysing tax non-compliance in depth is given in Switzerland should be discussed on a political level. Especially as some methods, for example the promising random audits, are costly, resource intensive and place a significant burden on the selected and audited taxpayers.

A promising approach is to address tax non-compliance by the three paradigms derived by Alm (2012): the enforcement, service and trust paradigms. Under the first paradigm, tax non-compliance is fought with audits and penalties. The second aims to increase compliance by an improved service level on the part of the tax authorities, treating the taxpayer less as a potential criminal, and more as a client. The third paradigm addresses the link between tax compliance 
and tax culture: tax compliance increases if taxpayers are, for example, more aware that government services are paid with their taxes. In our view, measuring the tax gap just to know its size is of limited use. However, increasing empirical evidence would support addressing tax non-compliance on all three paradigm levels. Therefore, the goal of analysing the tax gap should be to obtain a better understanding of its structure and of the motives of the taxpayer to non-comply, enabling the implementation of efficient measures against tax non-compliance.

\section{Appendix}

Table 10: Summary of Tax Gap Estimate Methodologies in the United Kingdom

\begin{tabular}{|c|c|c|}
\hline $\operatorname{tax}$ & component & main components of methodology ${ }^{1}$ \\
\hline \multirow{6}{*}{$\begin{array}{l}\text { Income Tax, } \\
\text { National Insurance } \\
\text { Contributions (NIC), } \\
\text { Capital Gains Tax }\end{array}$} & $\begin{array}{l}\text { Pay-as-you-earn (PAYE): small- } \\
\text { medium enterprises (SMEs) }\end{array}$ & $\begin{array}{l}\text { Bottom-up estimate based on random } \\
\text { audit results. }\end{array}$ \\
\hline & PAYE: large taxpayers & $\begin{array}{l}\text { Constructed estimate based on the } \\
\text { results for the SMEs. }\end{array}$ \\
\hline & $\begin{array}{l}\text { Self-assessment: individuals and } \\
\text { businesses }\end{array}$ & $\begin{array}{l}\text { Bottom-up estimate based on random } \\
\text { audit results. }\end{array}$ \\
\hline & Self-assessment: large partnership & $\begin{array}{l}\text { Constructed estimate bases on error } \\
\text { levels comparable to results for the } \\
\text { SMEs. }\end{array}$ \\
\hline & $\begin{array}{l}\text { Nondeclaration of income by } \\
\text { individuals not in self-assessment } \\
\text { "Moonlighters" } \\
\text { "Ghosts" }\end{array}$ & $\begin{array}{l}\text { Bottom-up estimate based on cross- } \\
\text { matching PAYE data with third party } \\
\text { information. Estimate based on study } \\
\text { results. Estimate based on labor force } \\
\text { survey and immigration data. }\end{array}$ \\
\hline & Avoidance & $\begin{array}{l}\text { Estimate constructed using avoidance } \\
\text { schemes being tracked in the "risk } \\
\text { register." }\end{array}$ \\
\hline \multirow[t]{3}{*}{ Corporation Tax } & $\begin{array}{l}\text { Large business services (LBS) } \\
\text { clients }\end{array}$ & $\begin{array}{l}\text { Constructed estimate based on data } \\
\text { on Tax under Consideration (TuC) } \\
\text { data from the LBS case management } \\
\text { system. }\end{array}$ \\
\hline & Large and complex businesses & $\begin{array}{l}\text { Constructed estimate based on the } \\
\text { results for the LBS clients. }\end{array}$ \\
\hline & Small-medium enterprises & $\begin{array}{l}\text { Bottom-up estimate based on } \\
\text { random-audit results. }\end{array}$ \\
\hline
\end{tabular}




\begin{tabular}{|c|c|c|}
\hline $\operatorname{tax}$ & component & main components of methodology ${ }^{1}$ \\
\hline VAT & & $\begin{array}{l}\text { Top down estimate based on } \\
\text { consumption statistics. (A bottom-up } \\
\text { estimate is also performed in order } \\
\text { to determine the composition of the } \\
\text { gap). }\end{array}$ \\
\hline \multirow[t]{2}{*}{ Excises } & Alcoholic beverages, Tobacco & $\begin{array}{l}\text { Top-down estimate based on } \\
\text { consumption statistics. }\end{array}$ \\
\hline & Petroleum fuels & $\begin{array}{l}\text { Top-down estimate based on travel } \\
\text { distance statistics and fleet characteris- } \\
\text { tics, and "cross-border shopping." }\end{array}$ \\
\hline
\end{tabular}

Notes: ${ }^{1}$ There are other components to the total estimate for some of these items, such as the addition of the value of nonpayment; this table only summarizes the main estimation methodology component.

Source: IMF (2013, p. 10/Table 1).

Figure 5: Swiss Tax Revenue Breakdown in 2011 by Tax Type and State Level

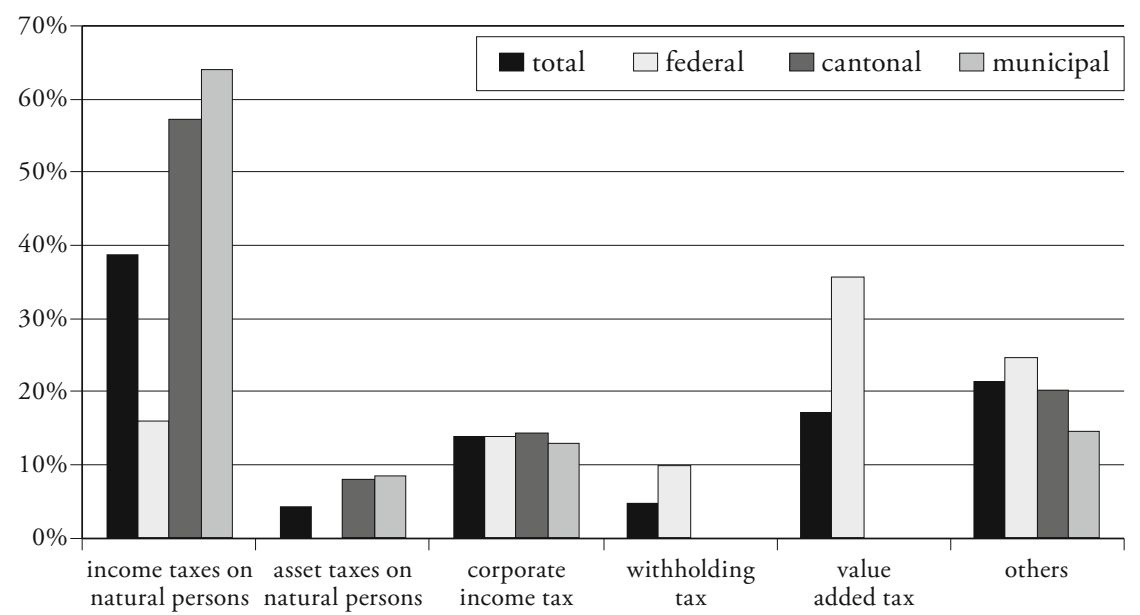

Source: Own calculation and illustration based on Eidgenössische Finanzverwaltung EFV (2013, pp. 36/46/57). 


\section{References}

AHV/IV (2014), „Beiträge der Selbständigerwerbenden an die AHV, die IV und die EO“, Bulletin [Merkblatt] 2.02, Version January 2014, published by the Information Centre [Informationsstelle] AHV/IV in Cooperation with the Federal Office for Social Security [Bundesamt für Sozialversicherungen].

Allingham, Michael G. and Agnar Sandmo (1972), "Income Tax Evasion: A Theoretical Analysis”, Journal of Public Economics, 1, pp. 323-338.

Alm, James (2012), "Measuring, Explaining, and Controlling Tax Evasion: Lessons from Theory, Experiments, and Field Studies", International Tax Public Finance, 19(1), pp. 54-77.

Alm, James, Roy Bahl, and Matthew N. Murray (1991), "Tax Base Erosion in Developing Countries", Economic Development and Cultural Change, 39(4), pp. 849-872.

Alm, James and Juan L. Gomez (2008), "Social Capital and Tax Morale in Spain", Economic Analysis and Policy, 38(1), pp.73-87.

Alm, James and Sarah Jacobson (2007), "Using Laboratory Experiments in Public Economics”, National Tax Journal, 60(1), pp. 129-152.

Alm, James and Benno Torgler (2006), "Culture Differences and Tax Morale in the United States and in Europe", Journal of Economic Psychology, 27, pp. 224-246.

Andreoni, James, Brian Erard, and Jonathan Feinstein (1998), "Tax Compliance", Journal of Economic Literature, 36(2), pp. 818-860.

Baldini, Massimo, Paolo Bosi, and Michele Lalla (2009), "Tax Evasion and Misreporting in Income Tax Returns and Household Income Surveys", Politica economica - Journal of Economic Policy, 25(3), pp. 333-348.

Benedek, Dóra and Orsolya Lelkes (2011), "The Distributional Implications of Income Under-Reporting in Hungary”, Fiscal Studies, 32(4), pp. 539-560.

Black, Theodore, Kim Bloomquist, Edward Emblom, Andrew Johns, Alan Plumley, and Esmeralda Stuk (2012), "Federal Tax Compliance Research: Tax Year 2006 Tax Gap Estimation”, Analysis \& Statistics Working Paper, IRS Research.

Bloomquist, Kim M. (2006), "A Comparison of Agent-Based Models of Income Tax Evasion”, Social Science Computer Review, 24(4), pp.411-425.

Bloomquist, Kim M. (2011), "Tax Compliance as an Evolutionary Coordination Game: An Agent-Based Approach”, Public Finance Review, 39(1), pp. 25-49.

Bollinger, Christopher R. (1998), "Measurement Error in the Current Population Survey: A Nonparametric Look", Journal of Labor Economics, 16(3), pp. 576-594. 
Bound, John and Alan B. Krueger (1991), "The Extent of Measurement Error in Longitudinal Earnings Data: Do Two Wrongs Make a Right?", Journal of Labor Economics, 9(1), pp. 1-24.

Breusch, Trevor (2005), "Estimating the Underground Economy Using MIMIC Models", Working Paper, Version November 2005, The Australian National University, http://econwpa.repec.org/eps/em/papers/0507/0507003. pdf.

Brown, Bob and Drew Johns (2007), "National Research Program - Methods and Plans", The IRS Research Bulletin, Proceedings of the 2007 IRS Research Conference, pp. 125-143.

Buehn, Andreas and Friedrich Schneider (2007), "Shadow Economies and Corruption all over the World: Revised Estimates for 120 Countries”, Economics: The Open-Access, Open-Assessment E-Journal, 1 (2007-9) (Version 2), pp. 1-53.

Buehn, Andreas and Friedrich Schneider (2012), "Size and Development of Tax Evasion in 38 OECD Countries: What Do We (Not) Know?”, CESifo Working Paper No.4004, CESifo Group Munich.

Bundesamt FÜR STATISTIK BFS (2013), „Haushaltsbudgeterhebung 2011: Kommentierte Ergebnisse und Tabellen“, BFS Aktuell, http://www.bfs.admin.ch/ bfs/portal/de/index/themen/20/22/publ.html?publicationID=5261.

BundesRat (1962), „Bericht des Bundesrates an die Bundesversammlung zur Motion Eggenberger betreffend wirksamere Bekämpfung der Steuerdefraudation (vom 25. Mai 1962)“, Bundesblatt, 114(23), pp. 1057-1117.

Bundesrat (1974), „Kleine Anfrage Eggenberger vom 27. November 1973 (Nr. 516): Steuerdefraudation“, Amtliches Bulletin der Bundesversammlung, 1, pp. 17-18.

BundesRat (1983), „Bericht über Massnahmen zur Bekämpfung der Steuerhinterziehung (Postulat des Nationalrates 81.541 vom 19. März 1982)“, Bundesblatt, 136(1), pp. 121-140.

Cagan, Phillip (1958), "The Demand for Currency Relative to the Total Money Supply”, Journal of Political Economy, 66(4), pp. 303-328.

Cebula, Richard J. (2013), "New and Current Evidence on Determinants of Aggregate Federal Personal Income Tax Evasion in the United States", American Journal of Economics and Sociology, 72(3), pp.701-731.

Chan, Chris W., Coleen. S. Troutman, and David O’Bryan (2000), “An Expanded Model of Taxpayer Compliance: Empirical Evidence from the United States and Hong Kong", Journal of International Accounting, Auditing and Taxation, 9(2), pp. 83-103. 
Christian, Charles W. (1994), "Voluntary Compliance with the Individual Income Tax: Results from the 1988 TCMP Study", The IRS Research Bulletin, 1993/1994, pp. 35-42.

Cohn, Gustav (1884), „Die Steuerreform im Kanton Zürich und der Bundeshaushalt der Schweiz", FinanzArchiv / Public Finance Analysis, 1(1), pp.45-133.

Cowell, Frank. A. (1990), Cheating the Government: The Economics of Evasion, Cambridge: The MIT Press.

Cowell, Frank. A. and James. P. F. Gordon (1988), "Unwillingness to Pay: Tax Evasion and Public Good Provision", Journal of Public Economics, 36(3), pp.305-321.

CPB Netherlands Bureau for Economic Policy Analysis (2013), "Study to Quantify and Analyse the VAT Gap in the EU-27 Member States", Final Report to the European Commission (DG TAXUD), Project leader: CASE - Center for Social and Economic Research, Consortium leader: CPB Netherlands Bureau for Economic Policy Analysis, http://ec.europa.eu/taxation_customs/ resources/documents/common/publications/studies/vat-gap.pdf.

D’Alessio, Giovanni and Ivan Faiella (2002), "Non-Response Behaviour in the Bank of Italy's Survey of Household Income and Wealth", Temi di discussione del Servizio Studi No. 462, Banca d'Italia.

D’Aurizio, Leandro, Ivan Faiella, Stefano Iezzi, and Andrea Neri (2008), "The Under-Reporting of Households' Financial Assets in Italy", IFC Bulletin, 28, pp. 415-420.

Dellanno, Roberto and Friedrich Schneider (2006), "Estimating the Underground Economy by Using MIMIC Models: A Response to T. Breusch's Critique", Working Paper No 0607, Department of Economics, Johannes Kepler University of Linz.

Dhami, Sanjit and Ali al-Nowaini (2007), "Why Do People Pay Taxes? Prospect Theory Versus Expected Utility Theory", Journal of Economic Behavior \& Organization, 64(1), pp. 171-192.

Eidgenössische Finanzverwaltung EFV (2013), „Finanzstatistik der Schweiz 2011: Jahresbericht", http://www.efv.admin.ch/d/downloads/finanzstatistik/ Berichterstattung/2013/Jahresbericht_Finanzstatistik_2011-d.pdf.

Eidgenössische Steuerverwaltung ESTV (1944), „Über das Ausmass der Steuerhinterziehung bei Wertschriften und Sparguthaben: Untersuchung auf Grund der Wehropferstatistik", Swiss Journal of Economics and Statistics, 80(1), pp. 183-188.

Eidgenössische Steuerverwaltung ESTV (2010), „Daten aus der Geschichte der Bundessteuern", published by the Swiss Tax Conference [Schweiz. 
Steuerkonferenz SSK], Version September 2010, http://www.ub.unibas.ch/ digi/a125/sachdok/2012/BAU_1_5763061.pdf.

Eidgenössische Steuerverwaltung ESTV (2013), „Die Besteuerung von Obligationen und weiteren Finanzinstrumenten", published by the Swiss Tax Conference [Schweiz. Steuerkonferenz SSK], Version August 2013, https:// www.estv.admin.ch/estv/de/home/allgemein/dokumentation/publikationen/ weitere-publikationen/dossier-steuerinformationen.html.

Eidgenössische Steuerverwaltung ESTV (2014a), „Die geltenden Steuern von Bund, Kantonen und Gemeinden", published by the Swiss Tax Conference [Schweiz. Steuerkonferenz SSK], Version May 2014, https://www.estv. admin.ch/estv/de/home/allgemein/dokumentation/publikationen/weiterepublikationen/dossier-steuerinformationen.html.

Eidgenössische Steuerverwaltung ESTV (2014b), „Fiskaleinnahmen des Bundes 2013“, https:/www.estv.admin.ch/estv/de/home/allgemein/dokumentation/zahlen-und-fakten/steuerstatistiken/fiskaleinnahmen-des-bundes/ fiskaleinnahmen-des-bundes-2013.html.

Elffers, Henk, Russel H. Weigel, and Dick J. Hessing (1987), “The Consequences of Different Strategies for Measuring Tax Evasion Behavior", Journal of Economic Psychology, 8(3), pp.311-337.

Erard, Brian and Jonathan S. Feinstein (1994), „The Role of Moral Sentiments and Audit Perceptions in Tax Compliance", Public Finance, 49(Supplement), pp. 70-89.

ERnst, URs (1983), Die Wohlstandsverteilung in der Schweiz: Stand und Entwicklung der personellen Einkommens- und Vermögensverteilung, Diessenhofen: Rüegger.

Feige, Edgar L. (1979), "How Big Is the Irregular Economy?”, Challenge, 22(5), pp. 5-13.

Feld, Lars P. and Bruno S. Frey (2004), "Illegal, Immoral, Fattening or What?: How Deterrence and Responsive Regulation Shape Tax Morale", Volkswirtschaftliche Beiträge, 26/2004, Fachbereich Wirtschaftswissenschaften, Philipps-Universität Marburg.

Feld, Lars P. and Bruno S. Frey (2006), "Tax Evasion in Switzerland: The Roles of Deterrence and Tax Morale", Working Paper No. 284, Institute for Empirical Research in Economics, University of Zurich.

Feld, Lars P. and Friedrich Schneider (2010), "Survey on the Shadow Economy and Undeclared Earnings in OECD Countries", German Economic Review, 11(2), pp. 109-149. 
Feldman, Naomi E. and Joel Slemrod (2007), "Estimating Tax Noncompliance with Evidence from Unaudited Tax Returns", The Economic Journal, 117(518), pp.327-352.

Fiorio, Carlo V. and Francecso D’Amuri (2005), "Workers Tax Evasion in Italy", Giornale degli Economisti e Annali di Economia, 64(2/3), pp. 247-270.

Fortin, Bernard, Guy Lacroix, and Marie-Claire Villeval (2007), "Tax Evasion and Social Interactions", Journal of Public Economics, 91(11/12), pp. 2089-2112.

Frey, Bruno S. and Lars P. Feld (2002), "Deterrence and Morale in Taxation: An Empirical Analysis", CESifo Working Paper No.760, CESifo Group Munich.

Frey, Bruno S. and Hannelore Weck (1983), "Estimating the Shadow Economy: A 'Naive' Approach”, Oxford Economic Papers, New Series, 35(1), pp. 23-44.

Frey, Bruno S. and Hannelore Weck-Hannemann (1984), "The Hidden Economy as an 'Unobserved' Variable”, European Economic Review, 26(1/2), pp. 33-53.

Friedland, Nehemiah, Shlomo Maital, and Aryeh Rutenberg (1978), "A Simulation Study of Income Tax Evasion”, Journal of Public Economics, 10(1), pp. 107-116.

Fu, Chunling (2008), “Three Essays on Income and Wealth", Dissertation, Simon Fraser University, Burnaby, Canada.

Fuest, Clemens and Nadine Riedel (2009), "Tax Evasion, Tax Avoidance and Tax Expenditures in Developing Countries: A Review of the Literature", Report prepared for the UK Department for International Development (DFID), Oxford University Centre for Business Taxation, http://r4d.dfid.gov. uk/PDF/Outputs/EcoDev/60670_TaxEvasionReportDFIDFINAL1906.pdf.

Gemmell, Norman and John Hasseldine (2012), "The Tax Gap: A Methodological Review”, Working Paper 09/2012 in Public Finance, Victoria Business School, Victoria University of Wellington.

Gutmann, Peter M. (1977), "The Subterranean Economy”, Financial Analysts Journal, 33(6), pp. 26-27+34.

Hashimzade, Nigar, Gareth D. Myles, Frank Page, and Matthew D. Rablen (2015), "The Use of Agent-Based Modelling to Investigate Tax Compliance", Economics of Governance, 16(2), pp. 143-164.

Hashimzade Nigar, Gareth D. Myles, and Binh Tran-Nam (2010), "New Approaches to the Economics of Tax Evasion", Working Paper, http://people. exeter.ac.uk/gdmyles/papers/pdfs/Non-euEva.pdf. 
Hofmann, Eva, Erik Hoelzl, and Erich Kirchler (2008), „Preconditions of Voluntary Tax Compliance: Knowledge and Evaluation of Taxation, Norms, Fairness, and Motivation to Cooperate", Journal of Psychology, 216(4), pp. 209-217.

Howald, Stefan (2011), „Eine ressentimentgeladene Einstellung provozieren: Kurze Geschichte über Versuche, die einheimische Steuerhinterziehung in der Schweiz zu berechnen", in Richtig Steuern: Wie mit Steuern jährlich 25 Milliarden an die Bevölkerung rückverteilt werden können, Hans Baumann and Beat Ringger, eds., pp. 160-172, Zürich: edition 8.

HRMC - HM Revenue \& Customs (2013a), "Measuring Tax Gaps 2013 Edition: Tax Gap Estimates for 2011-12", https:/www.gov.uk/government/ statistics/measuring-tax-gaps.

HRMC - HM Revenue \& Customs (2013b), "Methodological Annex for Measuring Tax Gaps 2013", https://www.gov.uk/government/statistics/measuring-tax-gaps.

IMF - International Monetary Fund (2013), "United Kingdom: Technical Assistance Report-Assessment of HMRC's Tax Gap Analysis”, by Juan Toro, Kentaro Ogata, Eric Hutton, and Selcuk Caner, IMF Country Report No. 13/314, Fiscal Affairs Department.

Iyer, Govind S., Philip M. J. Reckers, and Debra L. Sanders (2010), "Increasing Tax Compliance in Washington State: A Field Experiment", National Tax Journal, 63(1), pp.7-32.

Kapteyn, Arie and Jelmer Y. Ypma (2007), "Measurement Error and Misclassification: A Comparison of Survey and Administrative Data", Journal of Labor Economics, 25(3), pp. 513-551.

Kasipillai, Jeyapalan, Norhani Aripin, and Noor A. Amran (2003), „The Influence of Education on Tax Avoidance and Tax Evasion", eJournal of Tax Research, 1(2), pp. 134-146.

Kastlunger, Barbara, Stefan G. Dressler, Erich Kirchler, Luigi Mittone, and Martin Voracek (2010), „Sex Differences in Tax Compliance: Differentiating between Demographic Sex, Gender-Role Orientation, and Prenatal Masculinization (2D:4D)", Journal of Economic Psychology, 31(4), pp. 542-552.

Kaufmann, Daniel and Aleksander Kaliberda (1996), "Integrating the Unofficial Economy into the Dynamics of Post-Socialist Economies: A Framework of Analysis and Evidence", Policy Research Working Paper 1691, The World Bank. 
Kazemier, Brugt (1990), "Concealed Interest Income of Households in the Netherlands: 1977, 1979 and 1981", National Accounts Occasional Papers No. 039, Netherlands Central Bureau of Statistics.

Kirchgässner, Gebhard (2007), „Direkte Demokratie, Steuermoral und Steuerhinterziehung: Erfahrungen aus der Schweiz", Perspektiven der Wirtschaftspolitik, 8(1), pp.38-64.

Kirchler, Erich, Stephan Muehlbacher, Barbara Kastlunger, and IngRId WAHL (2007), „Why Pay Taxes? A Review of tax Compliance Decisions", Working Paper 07-30, Andrew Young School of Policy Studies, Georgia State University.

Klevenn, Henrik J., Martin B. Knudsen, Claus T. Kreiner, Søren Pedersen, and Emmanuel Saez (2011), "Unwilling or Unable to Cheat? Evidence from a Tax Audit Experiment in Denmark", Econometrica, 79(3), pp. 651-692.

Konrad Kai A. and Salmai Qari (2009), „The Last Refuge of a Scoundrel? Patriotism and Tax Compliance”, IZA Discussion Paper No. 4121, Institute for the Study of Labor.

Lackó Mária (1998), “The Hidden Economies of Visegrád Countries in International Comparison: A Household Electricity Approach", in Hungary: Towards a Market Economy, László Halpern and Charles Wyplosz, eds., pp. 128-152, Cambridge: Cambridge University Press.

Landrathe Kanton Glarus (1889), Memorial für die ordentliche Landsgemeinde des Kantons Glarus vom Jahr 1889. Vom Landrathe berathen in den Sitzungen vom 22. August, 26. September und 14. November 1888 und 9., 29. und 30. Januar, 5., 6., 13. und 27. Februar und 5. März 1889, Schwanden: Buchdruckerei von D. Fschudn=Vebin.

Lardi, Peter (1970), Empirische Untersuchung zur personellen Einkommensverteilung in der Schweiz, Dissertation, Universität Basel, Riehen: A. Schudel \& Co. AG.

Levitt, Steven D. and John A. List (2007), "What do Laboratory Experiments Measuring Social Preferences Reveal about the Real World?", Journal of Economic Perspectives, 21(2), pp. 153-174.

Lyssiotou, Panayiota, Panos Pashardes, and Thanasis Stengos (2004), "Estimates of the Black Economy Based on Consumer Demand Approaches", The Economic Journal, 114(497), pp. 622-640.

Matsaganis, Manos, Dóra Benedek, Maria Flevotomou, Orsolya Lelkes, Daniela Mantovani, and Sylwia Nienadowska (2010), "Distributional Implications of Income Tax Evasion in Greece, Hungary and Italy", Munich Personal RePEc Archive (MPRA) Paper No. 21465, Munich University Library. 
Matsaganis, Manos and Maria Flevotomou (2010), "Distributional Implications of Tax Evasion in Greece", Hellenic Observatory Papers on Greece and Southeast Europe GreeSE No. 31, The Hellenic Observatory, The London School of Economics and Political Science.

Meier, Alfred (1984), „Die Bekämpfung der Steuerhinterziehung in der Schweiz. Georg Schanz' „Die Steuern der Schweiz“ und die Gegenwart“, FinanzArchiv / Public Finance Analysis, 42(3), pp. 490-508.

Moore, Jefrrey C., Linda L. Stinson, and Edward J. Welniak (2000), "Income Measurement Error in Surveys: A Review", Journal of Official Statistics, 16(4), pp.331-361.

Munz, Hans (1944), Steuerhinterziehung - ein Massenphänomen in der Schweiz, Erweiterter Sonderabdruck aus der „Tat“, Band 33, Zürich: Landesring der Unabhängigen.

Myles, Gareth D. and Robin A. Naylor (1996), "A Model of Tax Evasion with Group Conformity and Social Customs", European Journal of Political Economy, 12(1), pp. 49-66.

Noth, Albert (1975), Die personelle Einkommensverteilung in der Schweiz 1949 bis 1968, Dissertation, Universität Freiburg, Freiburg.

OECD - Organisation for Economic Co-operation and Development (2002), Measuring the Non-Observed Economy: A Handbook, Paris.

OECD - Organisation for Economic Co-operation and Development (2004), "Compliance Risk Management: Use of Random Audit Programs", Information Note, Forum on Tax Administration Compliance Sub-Group, Centre for Tax Policy and Administration, http://www.oecd.org/ctp/administration/33818547.pdf.

OECD - Organisation for Economic Co-operation and Development (2008), "Monitoring Taxpayers' Compliance: A Practical Guide Based on Revenue Body Experience", Final Report, Forum on Tax Administration Compliance Sub-Group, Centre for Tax Policy and Administration, http:// www.oecd.org/tax/administration/40947920.pdf.

OECD - Organisation for Economic Co-operation and Development (2013), Revenue Statistics 1965-2012, OECD Publishing.

OfFice fÉdÉrAl DE la StatistiQue OFS (2013), «Inventaires des méthodes d'estimation du PIB suisse», Version March 2013, http://www.bfs.admin.ch/bfs/ portal/fr/index/themen/04/02/01/dos/04.html.

Paulus, Alari (2013), "Tax Evasion and Measurement Error: An Econometric Analysis of Income Survey Data Linked with Tax Records", Working Paper, Version July 2013, University of Essex. 
Pecho Trigueros, Miguel, Fernando Pelaez Longinotti, and Jorge SánChez Vecorena (2012), "Estimating Tax Noncompliance in Latin America: 2000-2010", Working Paper No.3-2012, Tax Studies and Research Directorate, Centro Interamericano de Administraciones Tributarias - CIAT.

Pedersen Søren (2003), "The Shadow Economy in Germany, Great Britain and Scandinavia: A Measurement Based on Questionnaire Surveys", Study No. 10, Rockwool Foundation.

Pickhardt, Michael and Aloys Prinz (2014), "Behavioral Dynamics of Tax Evasion - A Survey”, Journal of Economic Psychology, 40, pp. 1-19.

Pissarides, Christopher A. and Guglielmo Weber (1989), "An Expenditure-Based Estimate of Britain's Black Economy”, Journal of Public Economics, 39(1), pp. 17-32.

Pommerehne, Werner W. and Hannelore Weck-Hannemann (1996), "Tax Rates, Tax Administration and Income Tax Evasion in Switzerland", Public Choice, 88(1), pp. 161-170.

Prinz, Aloys (2004), „Steuermoral und Religiosität in Ost- und Westdeutschland“, Schmollers Jahrbuch: Zeitschrift für Wirtschafts- und Sozialwissenschaften/ Journal of Applied Social Science Studies, 124(4), pp. 511-537.

RAND Europe (2008), "Comparing How Some Tax Authorities Tackle the Hidden Economy", Report prepared for the UK National Audit Office, http:// www.nao.org.uk/wp-content/uploads/2008/04/0708341_comparing.pdf.

Reckon LLP (2009), "Study to Quantify and Analyse the VAT gap in the EU-25 Member States", commissioned by the European Commission, DirectorateGeneral for Taxation and Customs Union, http://ec.europa.eu/taxation_customs/resources/documents/taxation/tax_cooperation/combating_tax_fraud/ reckon_report_sep2009.pdf.

Rubin, Marcus (2011), "The Practicality of a Top Down Approach to the Direct Tax Gap", The IRS Research Bulletin, Recent Research on Tax Administration and Compliance: Selected Papers Given at the 2011 IRS-TPC Research Conference: New Perspectives on Tax Administration, pp. 109-127.

Sandmo, Agnar (2005), „The Theory of Tax Evasion: A Retrospective View“, National Tax Journal, 58(4), pp. 643-663.

Schaltegger, Christoph A. and Friedrich Schneider (2005), „Schattenwirtschaft: Ausmass, Gründe und Konsequenz für die Finanzpolitik “, Working Paper/Note, Johannes Kepler Universität Linz, Eidgenössische Steuerverwaltung ESTV.

Schanz, Georg (1890), Die Steuern der Schweiz in ihrer Entwicklung seit Beginn des 19. Jahrhunderts, Band II, Stuttgart: Verlage der J. G. Cotta'schen Buchhandlung. 
Schmid, Hans (1973), „Der Steuerwiderstand als Funktion des Steuersystems?“, Wirtschaft und Recht: Zeitschrift für Wirtschaftspolitik und Wirtschaftsrecht mit Einschluss des Sozial- und Arbeitsrechtes, 25(4), pp. 275-300.

Schneider, Friedrich (1994), "Determinanten der Steuerhinterziehung und der Schwarzarbeit im internationalen Vergleich", in Stand und Entwicklung der Finanzpsychologie, Christian Smekal und Engelbert Theurl, eds., pp. 247288, Baden-Baden: Nomos Verlagsgesellschaft.

Schneider, Friedrich (2005), "Shadow Economies around the World: What Do We Really Know?", European Journal of Political Economy, 21(3), pp. 598-642.

Schneider, Friedrich (2015), "Der Einfluss der Wirtschaftslage auf die Schattenwirtschaft in Deutschland und anderen OECD-Staaten in 2015: Kein einheitliches Bild", Research Paper, Version January 2015, Johannes Kepler Universität Linz.

Schneider, Friedrich and Andreas Buehn (2012), "Shadow Economies in Highly Developed OECD Countries: What Are the Driving Forces?” IZA Discussion Paper No. 6891, Institute for the Study of Labor.

Schneider, Friedrich and Andreas Buehn (2013), "Estimating the Size of the Shadow Economy: Methods, Problems and Open Questions", CESifo Working Paper No. 4448, CESifo Group Munich.

Schneider, Friedrich, Andreas Buehn, and Claudio E. Montenegro (2011), "Shadow Economies All over the World: New Estimates for 162 Countries from 1999 to 2007", in Handbook on the Shadow Economy, Friedrich Schneider, eds., pp.9-77, Cheltenham Glos: Edward Elgar.

Schneider, Friedrich and Dominik H. Enste (2000), "Shadow Economies: Size, Causes and Consequences”, Journal of Economic Literature, 38(1), pp. 77-114.

Schneider, Friedrich, Benno Torgler, and Christoph A. Schaltegger (2008), Schattenwirtschaft und Steuermoral, Kompaktwissen Band 6, Zürich/ Chur: Rüegger.

Schneider, Friedrich and Colin C. Williams (2013), The Shadow Economy, London: The Institute of Economic Affairs.

Schöchli, Hansueli (2012), „Auch Schweizer hinterziehen Steuern“, Neue Züricher Zeitung (NZZ), 20 November 2012, http://www.nzz.ch/auch-schweizer-hinterziehen-steuern-1.17825389.

Schweizerische Nationalkommission Justitia et Pax (1981), Die Bankeninitiative: Gutachten zur Initiative gegen den Missbrauch des Bankgeheimnisses und der Bankenmacht, Freiburg: Paulusdruckerei. 
SKAT - Danish Tax and Customs Administration (2009a), "Compliance with Tax Rules by Private Individuals in Denmark: Tax Year 2006", Report, http://www.skat.dk/getFile.aspx?Id=76359.

SKAT - Danish Tax and Customs Administration (2009b), "Compliance with Tax Rules by Businesses in Denmark: Tax Year 2006", Report, https:// www.skat.dk/getFile.aspx?Id=76358.

SKaT - Danish Tax and Customs Administration (2013), "Random Audits in Denmark", presentation by Søren Pedersen at the Nordic workshop on tax evasion on the $6^{\text {th }}$ March 2013 in Stockholm, http://ucfs.nek.uu.se/ digitalAssets/238/238407_1s--ren-pedersen.pdf.

Skatteverket (2014), "The Development of the Tax Gap in Sweden 2007-12”, Report, Swedish Tax Agency [Skatteverket], https://www.skatteverket.se/dow nload/18.15532c7b1442f256baeae28/1395223863657/The+development+of+ the+tax+gap+in+Sweden+2007-12.pdf.

Slemrod, Joel (2007), "Cheating Ourselves: The Economics of Tax Evasion", Journal of Economic Perspectives, 21(1), pp. 25-48.

Slemrod, Joel, Marsha Blumenthal, and Charles Christian (2001), "Taxpayer Response to an Increased Probability of Audit: Evidence from a Controlled Experiment in Minnesota", Journal of Public Economics, 79(3), pp. 455-483.

Slemrod, Joel and Caroline Weber (2012), "Evidence of the Invisible: Toward a Credibility Revolution in the Empirical Analysis of tax Evasion and the Informal Economy", International Tax Public Finance, 19(1), pp. 25-53.

Slemrod, Joel and Shlomo Yitzhaki (2002), "Tax Avoidance, Evasion, and Administration", in Handbook of Public Economics, Alan J. Auerbach and Martin Feldstein, eds., Volume 3, pp. 1423-1470, North-Holland: Elsevier.

StaAtssekretariat für Wirtschaft Seco (2008), „Bruttoinlandprodukt, Bruttonationaleinkommen und verfügbares Bruttoeinkommen nach Einkommensansatz", Technical Note [Technische Notiz], Version October 2008, http://www.seco.admin.ch/themen/00374/00456/05380/index.html?lang=de.

Strahm, Rudolf H. (1978), Bildungsdossier Banken: Materialien zum Finanzplatz Schweiz und zur Banken-Initiative der SPS, Bern: Zentralsekretariat der SP Schweiz.

Swedish National Tax Agency (2008), "Tax Gap Map for Sweden: How Was It Created and How Can It Be Used?", Report 2008:1B, http://www.skatteverket. se/download/18.71004e4c133e23bf6db8000109879/Report_2008_1B.pdf.

Tanzi, Vito (1980), “The Underground Economy in the United States: Estimates and Implications", Banca Nazionale del Lavoro Quarterly Review, 33(135), pp. 427-453. 
Torgler, Benno (2003), Tax Morale: Theory and Empirical Analysis of Tax Compliance, Dissertation, Universität Basel, Basel.

Torgler, Benno (2007), Tax Compliance and Tax Morale: A Theoretical and Empirical Analysis, Cheltenham: Edward Elgar Publishing.

Torgler, Benno and Christoph A. Schaltegger (2006), "Tax Morale: A Survey with a Special Focus on Switzerland", Swiss Journal of Economics and Statistics, 142(3), pp.395-425.

Torgler, Benno and Neven T. Valev (2010), "Gender and Public Attitudes toward Corruption and Tax Evasion", Contemporary Economic Policy, 28(4), pp. 554-568.

Traxler, Christian (2010), "Social Norms and Conditional Cooperative Taxpayers", European Journal of Political Economy, 26(1), pp. 89-103.

Tsakumis, George T., Anthony P. Curatola, and Thomas M. Porcano (2007), "The Relation between National Cultural Dimensions and Tax Evasion", Journal of International Accounting, Auditing and Taxation, 16(2), pp. 131-147.

Van BaAlen, Brigitte (2013), "Gap-TVA: Approche multidimensionelle de la situation en Suisse", Swiss Federal Tax Authority [Administration fédérale des contributions AFC], http://www.estv.admin.ch/dokumentation/00075/00805/index.html?lang=fr.

Weck, Hannelore (1983), Schattenwirtschaft: Eine Möglichkeit zur Einschränkung der öffentlichen Verwaltung? Eine ökonomische Analyse, Frankfurt am Main: Peter Lang.

Weck, Hannelore, Werner W. Pommerehne, and Bruno S.Frey (1984), Schattenwirtschaft, München: Franz Vahlen.

Weck-Hannemann, Hannelore and Bruno S. Frey (1985), "Measuring the Shadow Economy: The Case of Switzerland", in The Economics of the Shadow Economy, Wulf Gaertner and Alois Wenig, eds., pp.76-104, Berlin, Heidelberg: Springer-Verlag.

Weck-Hannemann, Hannelore and Werner W. Pommerehne (1989), „Einkommensteuerhinterziehung in der Schweiz: Eine empirische Analyse“, Swiss Journal of Economics and Statistics, 125(4), pp. 515-556.

Weck-Hannemann, Hannelore, Werner W. Pommerehne, and Bruno S. Frey (1986), Die heimliche Wirtschaft: Struktur und Entwicklung der Schattenwirtschaft in der Schweiz, Bern/Stuttgart: Paul Haupt.

Yaniv, Gideon (1999), "Tax Compliance and Advance Tax Payments: A Prospect Theory Analysis”, National Tax Journal, 52(4), pp. 753-764.

Yitzhaкi, Shlomo (1974), „A Note on Income Tax Evasion: A Theoretical Analysis“, Journal of Public Economics, 3(2), pp. 201-202. 